\title{
The December 1965 Eruption of Kilauea Volcano, Hawaii
}

GEOLOGICAL SURVEY PROFESIONAL PAPER 607

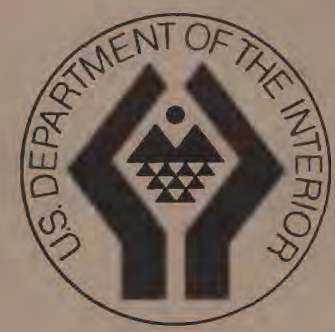





\section{The December 1965 Eruption of Kilauea Volcano, Hawaii}

By RICHARD S. FISKE and ROBERT Y. KOYANAGI

GEOLOGICAL SURVEY PROFESIONAL PAPER 607

An account of volcanic activity

that included a brief eruption,

a seismic crisis, and extensive

earth movements

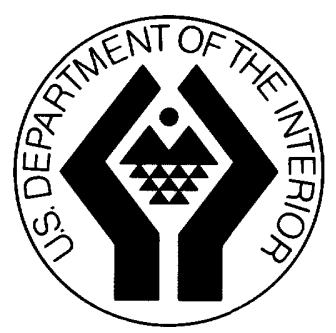




\section{UNITED STATES DEPARTMENT OF THE INTERIOR \\ STEWART L. UDALL, Secretary \\ GEOLOGICAL SURVEY \\ William T. Pecora, Director}

Library of Congress catalog-card No. GS 68-222

For sale by the Superintendent of Documents, U.S. Government Printing Office

Washington, D.C. 20402 - Price 35 cents (paper cover) 


\section{CONTENTS}

\section{Abstract} Acknowledgments Preeruption inflation of the summit............... Chronological narrative of the eruption............. Nature of ground movements.

Preliminary seismic studies.

Earthquake frequency and magnitude

Location of earthquakes. . . . . . . . . . . . . . .

Harmonic tremor.

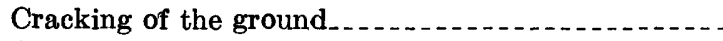

Collapse of the summit

\begin{tabular}{r|} 
Page \\
1 \\
1 \\
1 \\
1 \\
2 \\
4 \\
4 \\
5 \\
5 \\
6 \\
6 \\
8
\end{tabular}

Fage

Nature of ground movements-Continued

Changes in altitude.

Deposition of sulfur. 11

Distribution and character of lava................ 11

Lava erupted in Aloi Crater.................... 11

Lava erupted outside Aloi Crater............ 13

Source vents and drainback cracks.......... 13

Crustal foundering.

Volume of lava..... 16

Petrology and chemistry

Discussion

References cited. 18

\section{ILLUSTRATIONS}

FIGURE 1. Index map showing the relation of the summit area of Kilauea Volcano to the main structural features to the south

2. Record of north-south and east-west components of ground tilt at Uwekahuna, August 1964 to March 1966 . . .

3. Map showing ground tilt recorded at and near the summit of Kilauea Volcano.......

4. Graphs showing generalized chronology of events during the December 1965 activity of Kilauea Volcano.

5. Map of the area between Heake and Makaopuhi Craters showing distribution of lavas from recent eruptions

6. Photographs showing destruction of Hilina Pali Road at Kalanaokuaiki Pali............

7. Map showing change in altitude of bench marks in the summit area of Kilauea Volcano following the eruption of December 1965

8. Map showing change in altitude of bench marks along the Chain of Craters Road and Hilina Pali Road.

9. Photograph of lava and source fissures of th

10. Photograph of source fissure and drainback crack west of Kane Nui o Hamo

11. Maps showing flow directions of lava west of Kane Nui o Hamo

12. Photograph of spiral tree mold west of Kane Nui o Hamo

13. Photograph of the edge of the area affected by crustal foundering west of Kane Nui o Hamo ...

14. Map showing possible displacements of the area south and southeast of Kilauea caldera.-

15. Profile showing altitude and tilt changes south of Kalanaokuaiki Pali from July 1963 to January 1966

\section{TABLES}

TABLE 1. Modal composition of lava from the December 1965 eruption of Kilauea Volcano_......-

2. Chemical analyses and norms of lava from the December 1965 and December 1962 eruptions of Kilauea Volcano 



\title{
THE DEGEMBER 1965 ERUPTION OF KILAUEA VOLGANO, HAWAII
}

\author{
By Richard S. Frske and Robert Y. Koyanagi
}

\begin{abstract}
More than 1 million cubic yards of tholeiitic basalt was erupted from the upper east rift zone of Kilauea Volcano during a brief 6-hour period on December 24 and 25, 1965. The eruptive fissures opened in an en echelon zone about 2 miles long, from Aloi Crater eastward to Kane Nui o Hamo. The vigorous early stage of the eruption formed a 47-foot-deep lava lake in Aloi Crater and flooded about 150 acres of forest to the east. At a later stage, withdrawal of magma into the source fissures and other cracks drained the lava lake in Aloi Crater and considerably reduced the volume of lava in the flows remaining on the surface.

Measurements of ground tilt show that Kilauea summit inflated before the eruption, and that it abruptly deflated just before and during the eruption. Significantly, the summit continued to deflate for an additional 10-hour period after the eruption had ended. Precise leveling suggests that the summit of the volcano did not collapse simply, and that small subsidiary areas of collapse lay about $1.5 \mathrm{~km}$ north and $2 \mathrm{~km}$ southeast of Halemaumau.

The eruption marked only the beginning of a major seismic crisis that lasted for more than a week. Thousands of earthquakes were recorded, and preliminary results indicate that most of the epicenters lay in a narrow area extending from the upper east rift zone westward along the Koae fault zone into the Kau Desert. Hundreds of ground cracks and faults opened in this area, and precise leveling has shown that the area of cracking locally subsided nearly 6 feet.

The eruption ended as the tempo of ground cracking and earthquakes was just reaching a maximum. The rift zone is interpreted to have substantially dilated at this time, perhaps by seaward movement of the entire south flank of the volcano; this dilation created additional underground space in the rift system at a greater rate than magma was fed into it from the summit reservoir. Eruption of lava to the surface could no longer be maintained, and, moreover, much of the lava that had previously been erupted began to drain back into the rift zone. Tremor, earthquakes, ground cracking, and summit collapse continued vigorously for 10 hours after the eruption had ended, indicating that magma continued to move from the summit reservoir into the east rift zone. Apparently all this magma was accommodated underground in intrusive bodies.
\end{abstract}

\section{INTRODUCTION}

At about 2130 on December 24,1965 , Kilauea Volcano erupted from fissures on its east rift zone in the area extending from Aloi Crater to Kane Nui o Hamo, a low cinder and lava cone lying about 2 miles farther east (fig. 1). This eruption is the sixth on the east rift zone of Kilauea Volcano within the past 5 years, and in size and location it very nearly duplicated the somewhat smaller flank eruption of December 1962 (Moore and Krivoy, 1964). The eruption of December 1؟35 lasted for only about 6 hours, but the great swarm of earthquakes that preceded it by about 2 hours continued for more than a week after the eruption had ended. Moreover, the magnitude and extent of ground cracking that accompanied the activity far exceeded tl at which occurred during any of the eruptions of the past 5 years, and it may well have exceeded any that 1 as taken place in the upper east rift zone during the past 100 years.

Because of this exceptional ground movement and earthquake frequency, the overall activity of Decemk ar 1965 was of major importance; the eruption, on the other hand, can be considered only an incidental part of this activity. This report deals chiefly with the errption itself, the distribution and character of the n?w lava remaining at the surface, and the nature of the ground movements that accompanied the activity. A report describing the entire seismic crisis must await interpretation of the records of the many thousands of earthquakes that originated beneath Kilauea Volcano during that eventful period.

\section{ACKNOWLEDGMENTS}

The entire staff of the Hawaiian Volcano Obserratory, U.S. Geological Survey, made observations and gathered data used in this report, and their valuable help is gratefully acknowledged. The Hawaii Air N'ational Guard and the Hawaii County Civil Defense Agency provided air reconnaissance over the upper east rift zone, and the U.S. Navy kindly supplied vertical aerial photographs of the area covered by the Decemk $3 r$ 1965 lavas. Special thanks are also due the personnel of Hawaii Volcanoes National Park for observations and logistic support during and after the eruption.

\section{PREERUPTION INFLATION OF THE SUMMIT}

Daily plots of ground tilt recorded by the permanent short-base tiltmeter at Uwekahuna clearly traced the 


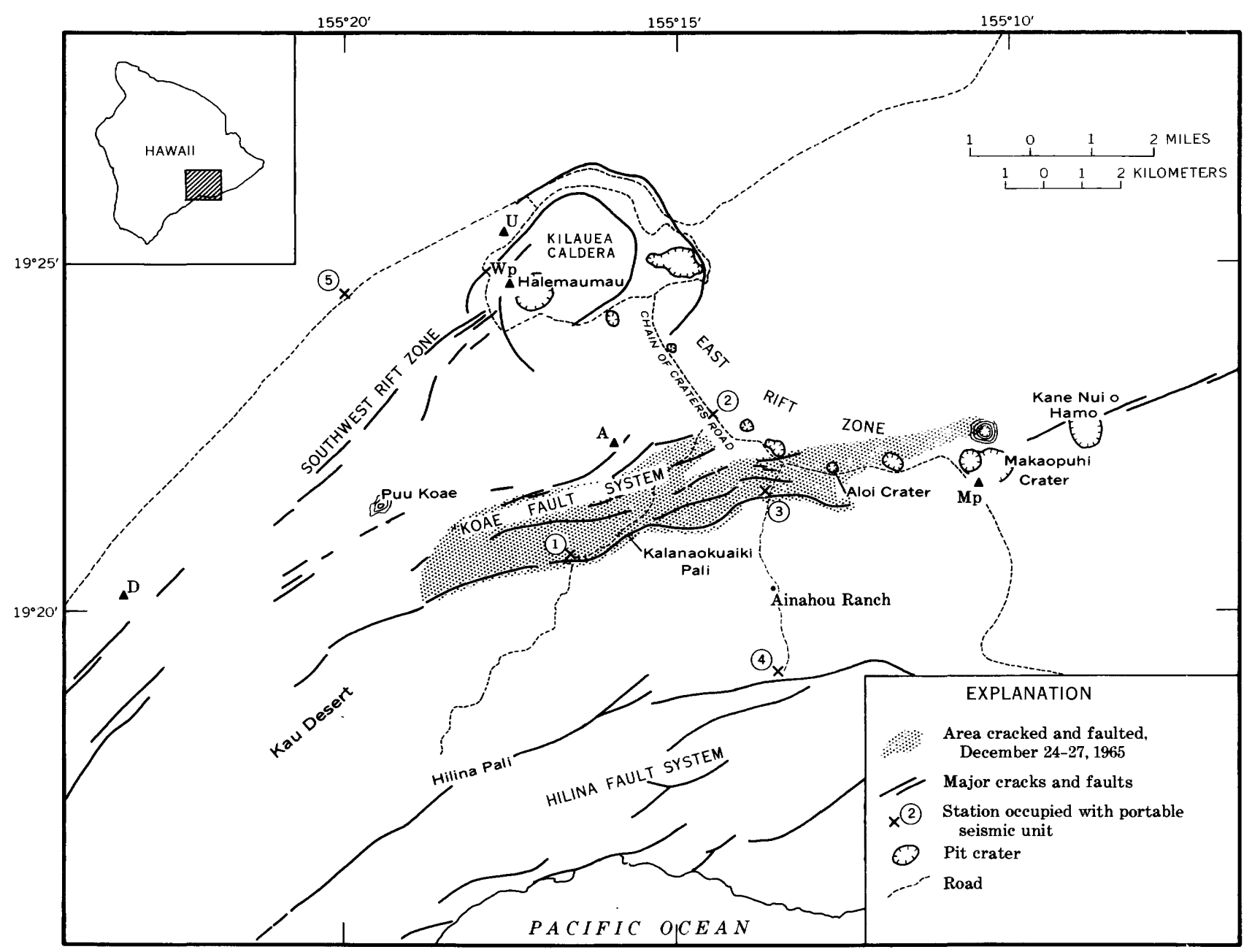

Figure 1.-Index map showing the relation of the summit area of Kilauea Volcano to the main structural features to the south. Numbers indicate portable seismic unit stations: 1, Hilina Pali Road; 2, Chain of Craters Road junction; 3, Ainahou Ranch Road; 4, Poliokeawe fault; 5, Kau Road localities. Stations of the permanent seismic network are designated by solid triangles: U, Uwekahuna; Wp, West Pit; D, Desert; A, Ahua; Mp, Makaopuhi.

inflation of the summit of Kilauea Volcano before the eruption (fig. 2). The general shape of the curve of inflation for the east-west component of tilt nearly duplicated the buildup that preceded the eruption of March 1965, although the total amount of tilt was not quite so great. On the other hand, the north-south component recorded much less inflation, and the abrupt increase in this component of tilt that preceded the activity of March 1965 was absent from the record before December 1965.

Periodic measurements of tilt with portable long-base tiltmeters were made at nine localities around the summit of the volcano, and the vectors at the near-summit stations clearly show the inflation of the summit area before the eruption (fig. 3). Moreover, by extending these tilt vectors back toward an approximate point of convergence, a rather poorly defined center of inflation can be located about 1-2 $\mathrm{km}$ east of Halemaumau.

\section{CHRONOLOGICAL NARRATIVE OF THE ERUFTION}

Although the harmonic tremor and swarm cf earthquakes that preceded the eruption began at about 1930 on December 24 (fig. 4), it was not until 2013 that a felt quake rattled through the residence area of $\mathrm{Ha}$ maii $\mathrm{Na}$ tional Park and gave warning of the impending activity.

A party left the Volcano Observatory at 2125 when it became apparent that an eruption was imminent. The exact time that lava first broke through the surface is unknown, but the brilliant orange glow that siddenly appeared above the upper east rift zone at 2130 probably marked the first appreciable fountaining in the vicinity of Aloi Crater. The observers rushed enstward along the Chain of Craters Road toward Aloi Crater, but were stopped about 500 feet west of the crater by dense clouds of sulfurous fumes and by ever-widening cracks in the road. 


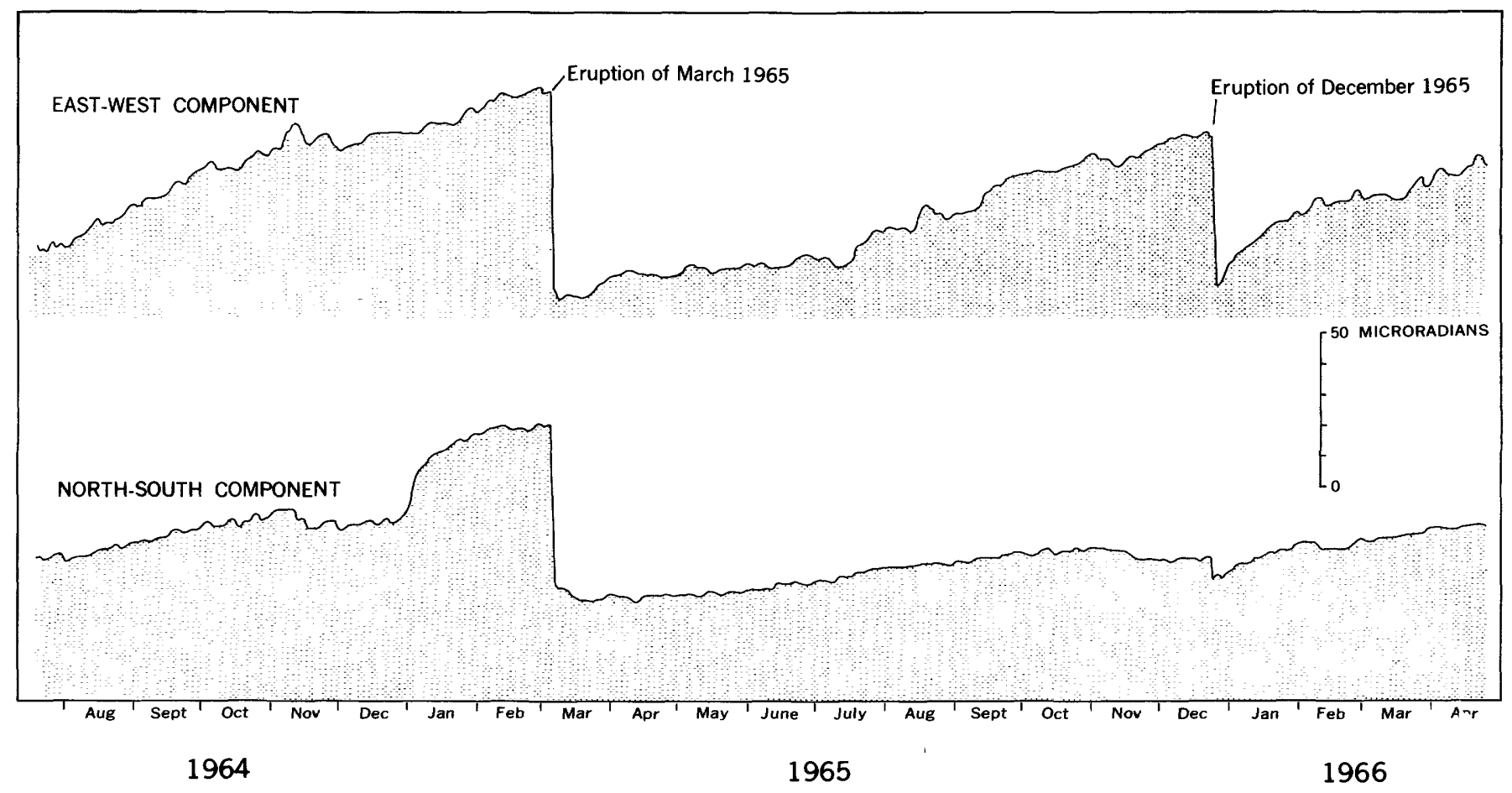

FIGURE 2.-Record of north-south and east-west components of ground tilt recorded daily by short-base water-tube tiltmeters at Uwekahuna for the period, August 1964 to March 1966.

For the next 2 hours the dense fume clouds prevented the observers from proceeding to a point where the eruption in Aloi Crater could actually be seen. Nevertheless, variations in the surging roar of the lava fountains and in the brilliance of the glow through the fume clouds gave a reasonable indication of the intensity of the eruption during this period.

From 2145 until 2205 the glow and roar of the fountains increased dramatically, and small amounts of punice and pele's hair fell on the areas south and southwest of Aloi Crater. A climax was reached at 2205 when a small amount of lava sprayed from one of the newly opened eracks just west of the crater and showered clots of glowing ejecta over a small area only 70 feet from where the observation party had temporarily grouped. The jetlike roar and the brilliant glow of the fountains in Aloi Crater continued only until 2210 and thereafter began to diminish. A gradual waning continued until 2400 when observers were finally able to make their way through the fume clouds to the overlook above the crater.

From the overlook it was immediately apparent that the eruption in the crater was nearly over. An en echelon line of smoldering feeder vents extended northeast across the floor of the crater and part way up the steep western and eastern walls. Small clots of incandescent lava were still being tossed lazily 5-10 feet into the air from two of the vents, and a distinct glow could be seen from the many cracks in the thin crust of the lava that still remained in the crater. The thin, continuous skin of lava that plastered the walls of the crater to a height of about 40 feet above its floor clearly indicated that much of the newly erupted lava had drained away before the observation parties were able to obtain a clear view of the crater.

The brilliant glow in the sky to the east, however, indicated that the eruption was continuing in the forest along the upper part of the east rift zone. Reconnaissance along the Chain of Craters Road showed that these outbreaks extended to the west flank of Kane Nui o Hamo, a low lava and cinder cone about 2 miles east of Aloi Crater. The mist and rain that were then being blown over the area diffused this glow to such an ex ent that it was difficult to pinpoint the exact position of the active vents and impossible to detect in detail any systematic migration of the new outbreaks that might have taken place. These eruptions began before 2325, because at that time an impressive new glow became visible in the east, beyond the dwindling glow from Aloi Crater. From 0015 on December 25 until just before 0400 the glow from these eruptions greatly diminished. At 0400 a brilliant glow suddenly appeared above the area about 11/2 miles east of Aloi Crater, and at the time it was thought that a new phase of the eruption was beginning. By 0410 however, the sky was nearly dark again, and later fieldwork has suggested that this glow was caused only by crustal foun- 


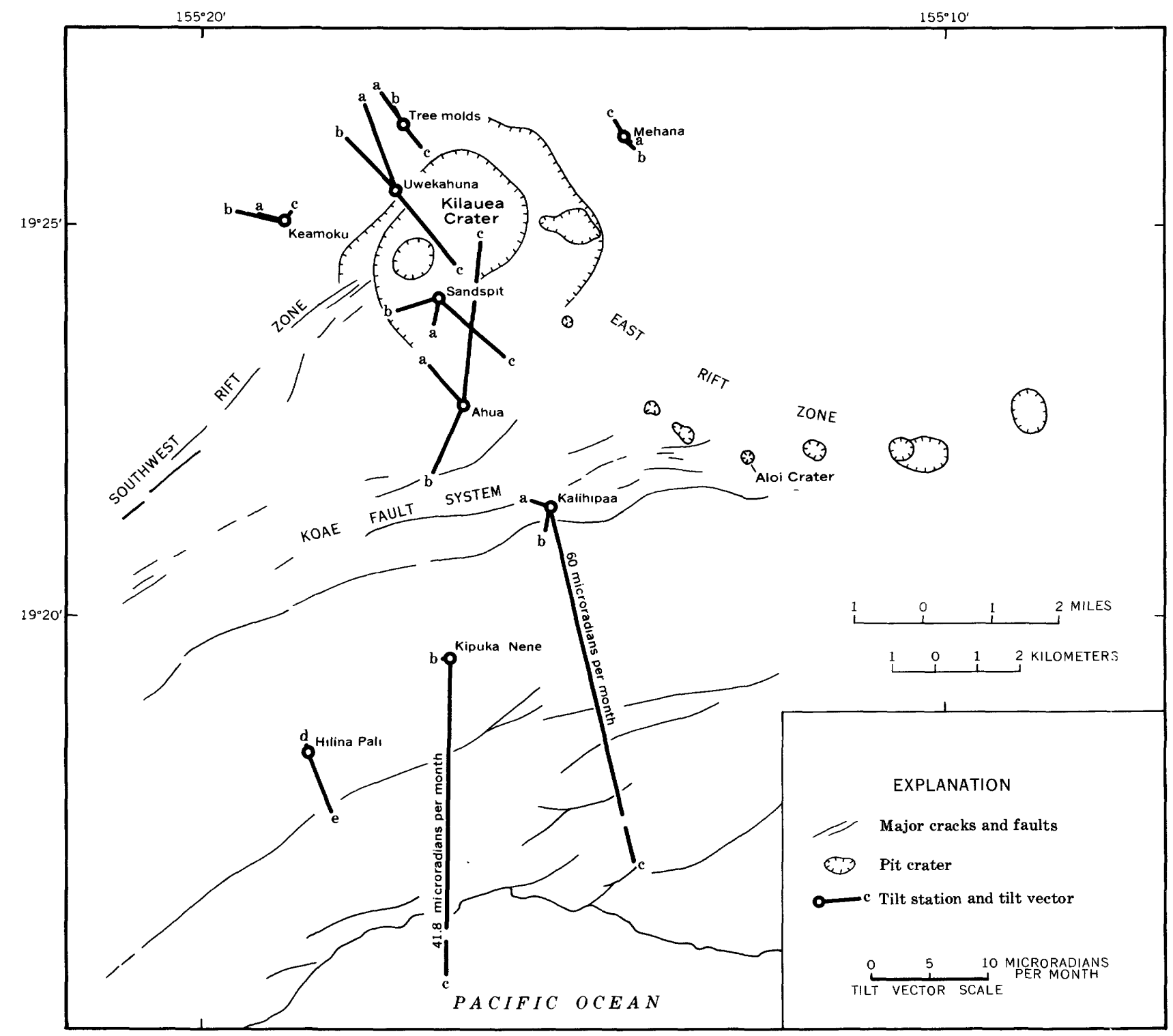

FrGURE 3.-Ground tilt recorded with portable long-base water-tube tiltmeters at nine stations at and near the summit of Kilauea Volcano for the following periods: (a) March 1965 to June 1965, (b) June 1965 to September 1965, (c) September 1965 to December 1965 (posteruption). Vectors (d) and (e) apply only to the Hilina Pali station and represent the tilt for the periods December 1964 to June 1965 and June 1965 to January 1966, respectirely. The magnitudes of the posteruption tilt vectors obtained at Kalihipaa and Kipuka Nene were so great that they could not be plotted at the same scale used for the other tilt vectors; they are therefore dashed, and the magnitude of each vector is labeled.

dering in the shallow pool of lava just west of Kane Nui o Hamo.

By 0500 the glow above the vents east of Aloi Crater was barely visible, and before sunrise on Christmas Day the eruption had ended.

\section{NATURE OF GROUND MOVEMENTS PREIIMINARY SEISMIC STUDIES}

As the fires of the eruption dwindled and died, the great swarm of earthquakes that accompanied the activity was still increasing in intensity. Thousands of earthquakes that originated during the continuing seismic crisis were recorded by the permanent seismic network of the Hawaiian Volcano Observatory and by a portable, jeep-mounted unit that was operated at five different localities on the flanks of Kilauea Volcano (fig. 1). This preliminary summary deals chiefly with the results obtained from the portable unit.

The portable seismic unit, consisting of a 2-channel system equipped with short-period, horizontal and vertical seismometers, was operated for 1- to 3-hour periods at each of the five localities. For normal operation the 

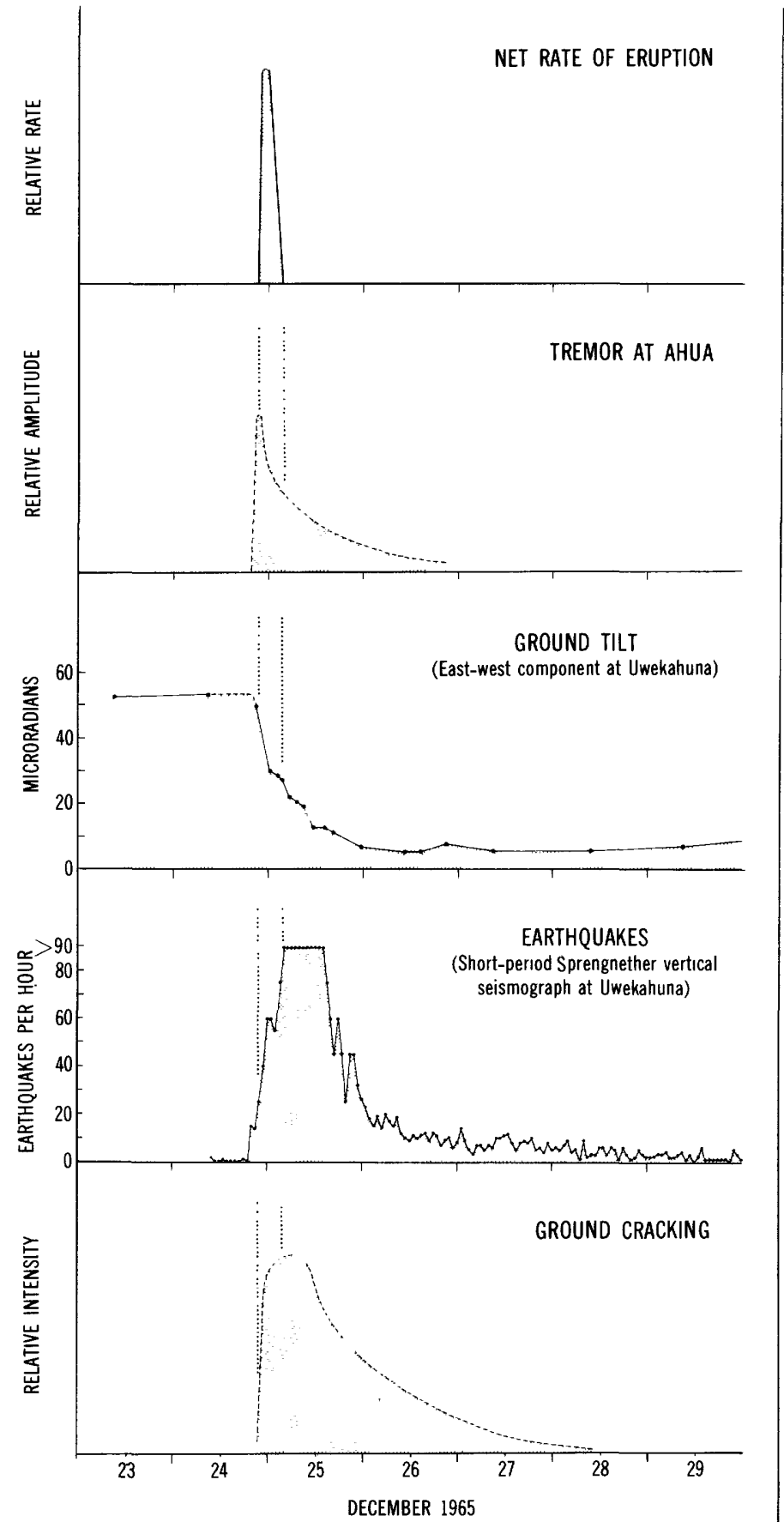

FIGURE 4.-Generalized chronology of events during the December 1965 activity of Kilauea Volcano. The duration of eruption has been projected downward (dotted lines) to emphasize that the eruption occupied only the early stage of the total activity.

system was set at a magnification of about 10,000 , peaking at a frequency of about 5 cycles per second.

\section{EARTHQUAKE FREQUENCY AND MAGNITUDE}

The seismic crisis began abruptly at 1929 on December 24 and rapidly increased in intensity. A strong-motion instrument (vertical short-period Sprengnether seismograph) at Uwekahuna recorded 15 earthquakes during the initial hour, and the rate increased to more than 90 per hour by 0400 on December 25 (fig. 4). Peak frequencies on seismograms were masked during the period of most intense activity, from about 0300 to 1400 on the 25th. After 1400 the frequency of quakes diminish 2 , and the frequency plot followed a hyperbolic decay curve to the end of the crisis. This frequency patterr is common for tectonic earthquakes and aftershocks. During the 168-hour period from December 24-31, more than 2,500 earthquakes, ranging in magnitude from 0.5 to 4.2 , were recorded at Uwekahuna.

More than 2,300 earthquakes of magnitude 0.1 or greater were recorded by the high-gain, portable instrument over scattered periods totaling only 26 horrs during the first 5 days of the crisis; during the peak of activity, more than 5 quakes per minute were register?d. If the entire crisis had been monitored with this instrument, it is likely that more than 10,000 earthquakes would have been recorded.

\section{LOCATION OF EARTHQUAKES}

Much additional work is needed before many of the earthquakes can be precisely located, but the available data clearly indicate that most of the epicenters lay along the parts of the Koae fault system and the upper part of the east rift zone that were badly broken by cracks and faults during the activity. An east-west distribution of epicenters in this zone is shown by variations in the arrival times of $P$-waves at the Desert and Makaopuhi seismometers of the permanent seismic notwork (fig. 1). During the period from December 28 to 31 , a maximum variation of 3.4 seconds was obtained in the arrival times of $\mathrm{P}$-waves from 69 selected ear $\mathrm{h}$ quakes, suggesting an epicentral distribution extending nearly the entire distance between the two stations. The lack of seismometers south of Ahua makes it diffic'lt to determine north-south focal distribution during this same period, but the average delay of $\mathrm{P}$-wave arrivals between the Ahua and West Pit seismometers implies an epicentral concentration south of the caldera area, presumably very close to Ahua.

Differences in $\mathrm{P}$ - and S-wave arrivals determired from 1,094 earthquakes recorded by the portable seismic unit also indicate that the largest concentration of enicenters was near the zone of cracking. A predominence of S-P interval values ranging from 1.5 to nearly 0 seconds, which correspond to epicentral radii of $\varepsilon-0$ $\mathrm{km}$ at " 0 " $\mathrm{km}$ depth, was observed at Hilina Pali Road (1), Chain of Craters Road junction (2), and Ainahou Ranch Road (3) localities (fig. 1). On the other hand, at the Poliokeawe fault (4) and Kau Road (5) locali- 
ties, south and north of the cracked area, respectively, S-P interval values ranging from 1 to 2 seconds were common. Such values indicate epicentral distances of about 5-10 km. A lack of S-P interval values of less than 1 second suggests a corresponding lack of earthquake activity in the immediate vicinity of these last two localities.

Finally, the general intensity of the seismic activity as recorded by the portable unit was significantly greater at the three localities within the cracked zone than it was at the two localities north and south of the zone. These differences of intensity also strongly suggest that the epicenters of most of the earthquakes lay within the zone of cracking.

HARMONIC TREMOR

Harmonic tremor began recording at 1929 on December 24 , the same time that the swarm of earthquakes began. The tremor rapidly increased in intensity (fig. 4 ), and by 2030, large amplitude tremor began to register on all the near-summit seismometers of the permanent seismic network. Especially high tremor amplitude, reaching its peak at 2153 on the 24 th, was recorded on the Ahua seismometer (fig. 4), only 4 miles from Aloi Crater. This high amplitude probably correlates with the period of maximum lava fountaining in and near the crater. As the fountaining diminished during the next few hours, the amplitude of tremor also decreased; after 0400 on December 25, when the eruption ended, the tremor diminished at a gradual rate throughout December 25 and during the first 16 hours of December 26. After 1600 on the 26th, tremor was faint and erratic and was recorded only by some nearby high-gain seismometers.

\section{CRACKING OF THE GROUND}

Hundreds of cracks opened within a narrow area at least 8 miles long and about 1 mile wide extending west from Kane Nui o Hamo, through the Chain of Craters Road, and into the Kau Desert (fig. 1). The cracks in the eastern part of this area extend into the upper east rift zone of Kilauea Volcano, and some of these cracks served as source fissures for the lavas of December 1965. The remainder lie within the Koae fault system, a highly broken zone of monoclines, tilted blocks, and grabens extending southwest across the Kau Desert. Only a few of the cracks that were active during December 1965 opened for the first time; most of them had already formed during previous episodes but opened wider in response to the renewed stresses.

The cracking of December 1965 was greater in total extent and magnitude than the cracking that accompanied any of the eruptions along the upper east rift zone during the past 5 years, and it clearly exceec ${ }^{7}, d$ that formed during the seismic crises of May 1938 (Jaggar, 1938), December 1950 (Finch, 1950), and Mry 1963 (Kinoshita, 1968). More than 22 cracks broke the Chain of Craters Road between Alae and Pauahi Craters, and hundreds more disrupted the roads leading to Ainahou Ranch and Hilina Pali (fig. 5).

About 58 inches of right-lateral offset was r?corded along the cracks that crossed the Chain of Craters Road. Twenty inches of this offset was produced along seven cracks that are definitely attributable to the activity of December 1965 because the cracks cut the dasher paint stripes of the highway centerline, last painted in August 1965.

The remaining 15 cracks record a total right-lateral offset of about 38 inches, but these cracks crossed the road at points between the painted stripes of the centerline, and thus are not positively related to the activity of December 1965. Some of them may well have formed during the eruptions or seismic crises that have taken place in the upper east rift zone in the past 16 years. Judging from the known offsets of the cracks that cut the painted stripes, however, it seems likely that at least half the offsets of uncertain origin were formed during the activity of December 1965. Thus, a total of perhaps 36 or 40 inches of right-lateral movement was distributed along the cracks between Alae and Pauahi Craters in December 1965.

Some part of this right-lateral movement might only be apparent, however, and could have been caused by simple tensional opening of the cracks which cross the road at an oblique angle; but half the cracks in the blacktop of the road showed no tensional opening whatsoever, and most of the remaining half opened d'atances of less than 1 inch (while, for example, showing rightlateral offsets of 2 or 4 inches). In contrast, the raad was buckled upward from 4-6 inches at two places between Aloi and Pauahi Craters.

Only two of the cracks that crossed the Chain of Craters Road showed appreciable vertical displacement. One of these cracks, about 400 feet east of Aloi Crater, produced a normal displacement of about 1 inch. southeast side down. The second, just east of Pauahi Crater, downdropped the road about 12 inches, also to th? southeast (as well as offsetting it about 8 inches in a rightlateral sense). This was the largest crack crossing the road, and it was at the same place where the road was badly broken during the seismic crisis of May 1938 (Jaggar, 1938).

The Hilina Pali Road was heavily damage along more than 2 miles of its length and was cornpletely destroyed at the point where it crosses Kalana okuaiki Pali (fig. 6). Moreover, the overall pattern of doforma- 


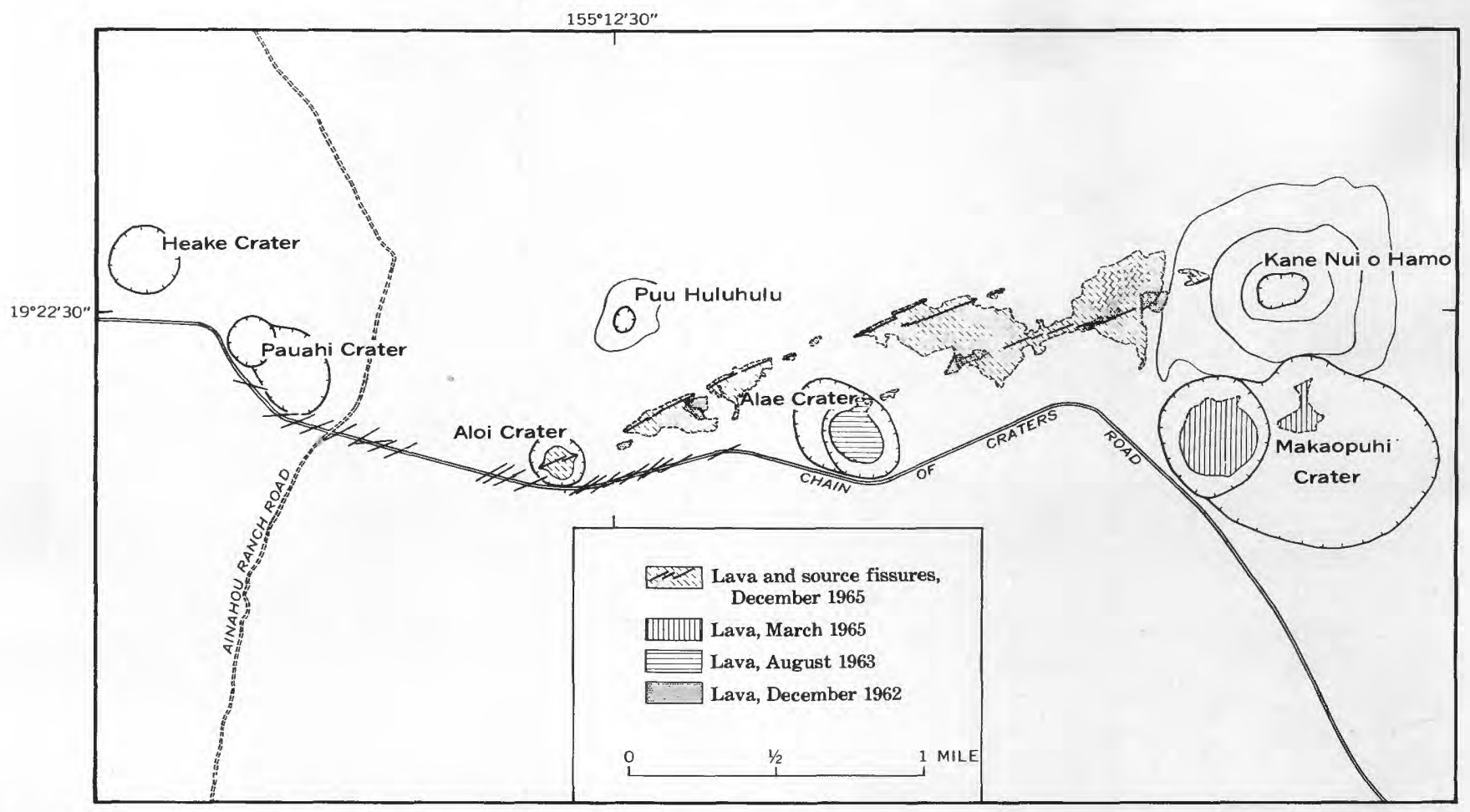

FIgURE 5.-Map of the area between Heake and Makaopuhi Craters, upper east rift zone of Kilauea Volcano, showing the lava and source vents of the eruption of December 1965 and the lava of the eruptions of March 1965, August 1963, and December 1962. The solid lines crossing the Chain of Craters Road are the 22 cracks that opened during the activity of December 1965; the crosshatched area just west of Kane Nui o Hamo marks the area affected by crustal foundering at about 0400 on December 25, 1965. Note that the lava of December 1962 is partly covered by the lava of December 1965.

tion along the Hilina Pali Road was considerably more complicated than it was along the Chain of Craters Road. Many of the cracks produced small tensional openings, but elsewhere, parts of the road surface were buckled into small chevronlike folds, producing a crude "washboard" effect. Comparatively few of the cracks showed a strike-slip component of offset, but where observed, left-lateral offsets were clearly dominant. This was especially true for the segment of the road extending a mile northeastward from Kalanaokuaiki Pali.

The crack at Kalanaokuaiki Pali, the largest formed during the activity of December 1965, marked the sharp southern boundary of the entire zone of cracking. Only a few tiny cracks crossed the roads leading to Hilina Pali and the Ainahou Ranch within a quarter of a mile south of the pali, and no new cracks were observed farther south.

The time relations of some of the individual cracks are known, and these relations serve to place broad limits on the timing of the entire episode of cracking. The cracks that broke the Chain of Craters Road in the vicinity of Aloi Crater opened before observers first arrived near the scene of the eruption at 2145 on December 24 . These cracks grew rapidly during the next hour when the eruption in Aloi Crater reached its climax; they achieved their maximum displacement by about 2300. The large crack in the Chain of Craters Road just east of Pauahi Crater had barely opened at 2145. By 0030 on December 25 it was conspicuous, but still easily crossed by automobile. By 0215 , however, the crack (and accompanying collapse of the road) had grown to such an extent that an automobile could barely be driven across it. At 0400 the crack had grown to its full size and had completely closed the road to vehicular traffic.

The opening of the large crack that broke the Ainahou Ranch Road at Kalanaokuaiki Pali was actually observed. Just before 2145 on December 24 the alarmed caretaker of the ranch attempted to evacuate the area. As he approached the pali from the south he paused momentarily to view the brilliant glow from the eruption in Aloi Crater, only 1 mile northeast. At 2145 a very large earthquake jolted the area, and a gaping crack about 3 feet wide and at least 20 feet deep opened across the road just a few feet north of where he was standing. It was impossible for him to drive his automobile across this crack, and he was forced to spend a lonely and terrifying night at the ranch.

The time relations of the crack that destroyed the Hilina Pali Road at Kalanaokuaiki Pali are also well 


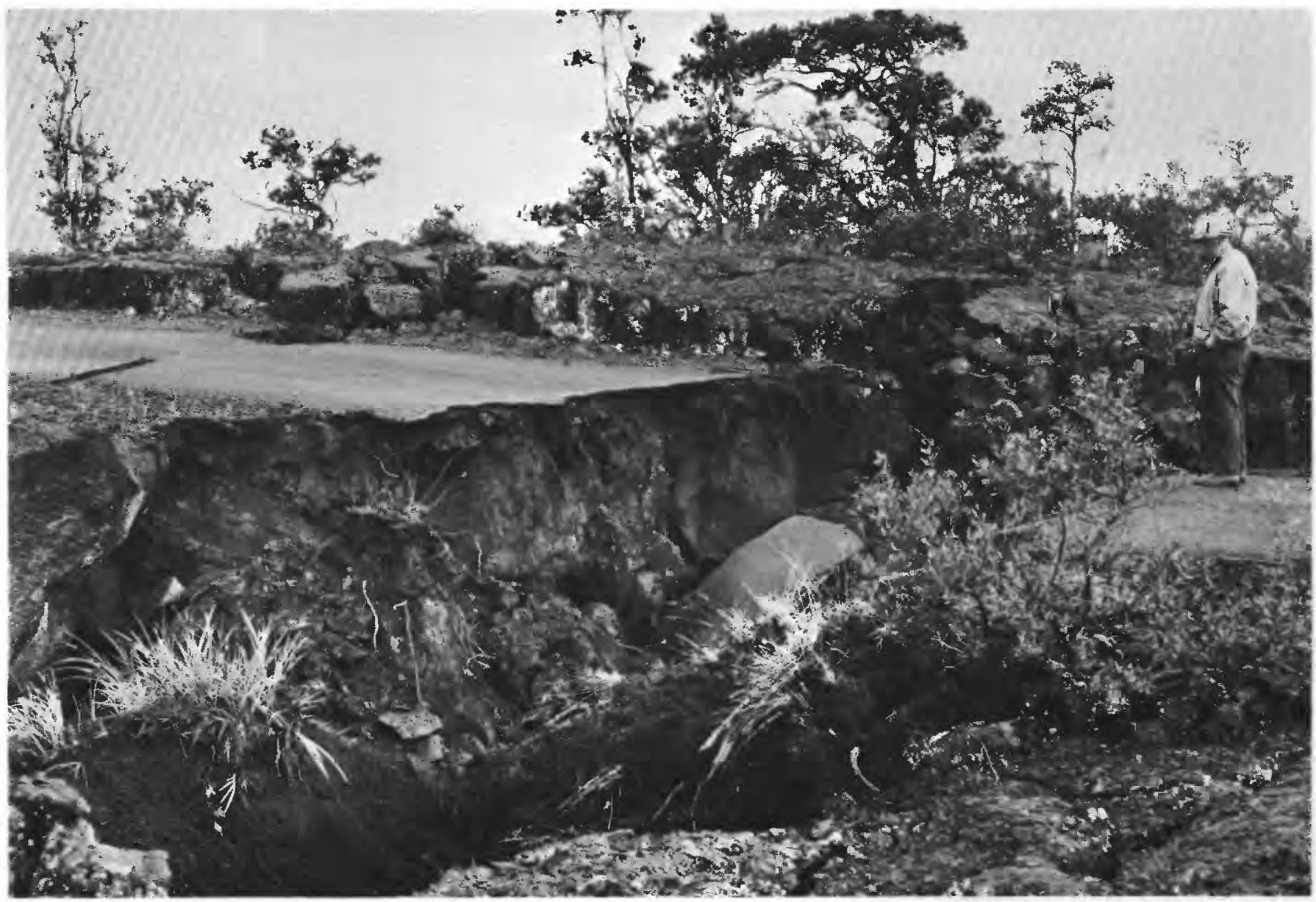

Figure 6.-DESTRUCTION OF HILINA

A. At 1100 on December 25 the road was crossed by only one main crack about 3 feet wide, and slumping from the edges of this crack had enlarged the gap in the road to about 8 feet.

known. At 0815 on December 25 the crack was barely 2 feet wide, and with careful maneuvering it would have been passable in a 4-wheel-drive vehicle. At 0840 the area was wrenched by an earthquake so violent that it nearly toppled a vehicle parked nearby, and the crack abruptly opened to about 5 feet (fig. $6 \mathrm{~A}$ ). This crack and others in the immediate area continued to widen as the swarm of earthquakes continued through December 25 and 26 , and by the morning of December 27 the main crack had opened to its full extent (fig. $6 B$ ).

In summary, different cracks opened at different times, and it is therefore possible to graph the development of the cracking only in a most generalized way (fig. 4). Specifically, however, the cracks that were observed to open in the eastern part of the disturbed zone formed during the eruption or soon thereafter, whereas the large crack to the west that cut the Hilina Pali Road opened later, during and just after the swarm of earthquakes reached its peak on December 25.

\section{COLLAPSE OF THE SUMMTT}

The onset of summit collapse at 1930 on December 24 was marked by the abrupt southeastern deflection of the long-period seismographs at Uwekahuna. Both the east-west and north-south components of tilt recorded by the short-base tiltmeter at Uwekahuna also recorded the collapse, and details of the east-west component are shown in figure 4.

Measurements of tilt with the long-base instruments at the stations near the summit of the volcano also clearly show the collapse, and the vectors from the Tree Molds, Uwekahuna, and Ahua stations show a rather poorly defined center of collapse located $1-2 \mathrm{~km}$ east of Halemaumau (fig. 3). The tilt vector obtained at Sandspit, on the other hand, suggests some local collapse in the area southeast of Sandspit, as is also suggested by the leveling data presented below.

Faults that opened near the piers of the Kalihipaa tilt station disrupted the local area to such an extent 


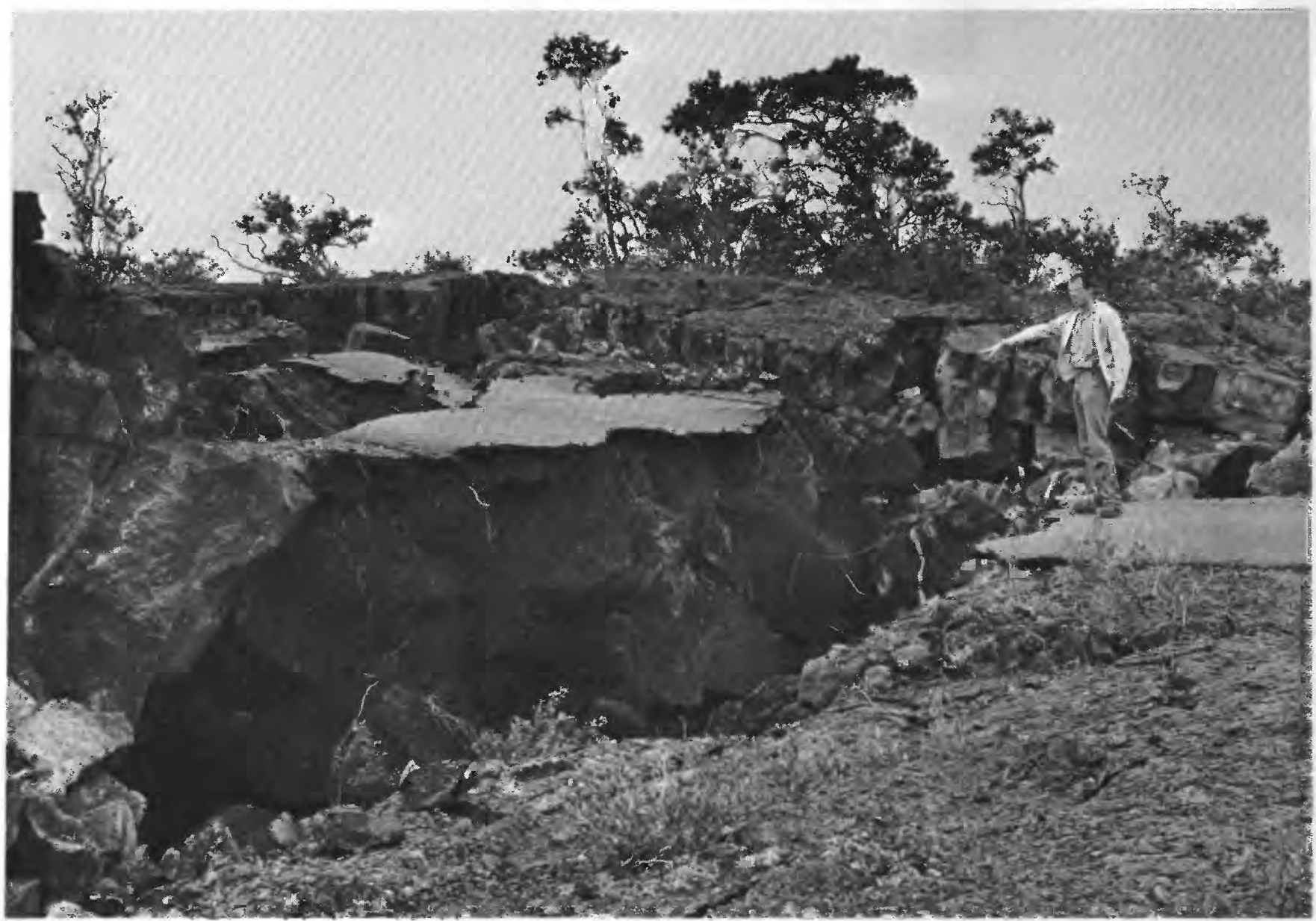

PALI ROAD AT KALANAOKUAIKI PALI

$B$. At 1000 on December 27 the main gap in the road had enlarged to a width of about 10 feet, and new cracks to the south (left) added to the destruction. The apparent vertical displacement at this locality totals about 3 or 4 feet, north side down.

that the piers were no longer within the measuring range of the tiltmeter. Precise leveling of these piers, however, indicated a tilt rate of 55 microradians per month in the direction S. $13.3^{\circ}$ E. for the period September 4, 1965, to January 5,1966 . This tilt vector has been plotted on figure 3 , but future measurements at this locality will not be made because changes of tilt caused by regional inflation or deflation can no longer be distinguished from those produced by local tectonic movements.

The unprecedented rates of tilt recorded at Kipuka Nene and Hilina Pali far exceeded the rates obtained during any period of time since measurements were first made at these stations in October 1959 and January 1960 , respectively. The southward orientation of both tilt vectors indicates that these stations did not respond to collapse of the summit, but suggests, instead, that at least part of the south flank of the volcano tilted seaward.

\section{CHANGES IN ALTITUDE}

Changes in altitude of the summit area and upper east rift of Kilauea Volcano are monitored by precise level lines originating at a reference bench mark near Bird Park (fig. 7), at the contact between Kilauea and Mauna Loa Volcanoes. Bird Park, however, lies only 4-6 $\mathrm{km}$ from the areas of maximum uplift and deflation of the summit, and it doubtless participates in these vertical movements to some extent. The magnitude of the movement at Bird Park is not known, but the areas of maximum inflation or deflation have always shown considerably greater changes than the area near Bird Park. Thus, the pattern of altitude change that does emerge gives a good indication of relative movements within the volcanic pile.

On Kilauea summit (fig. 7) two areas of subsidence and one smaller more elongate area of uplift are indicated. The area of uplift that trends northeast across Kilauea caldera did not, of course, inflate after the erup- 


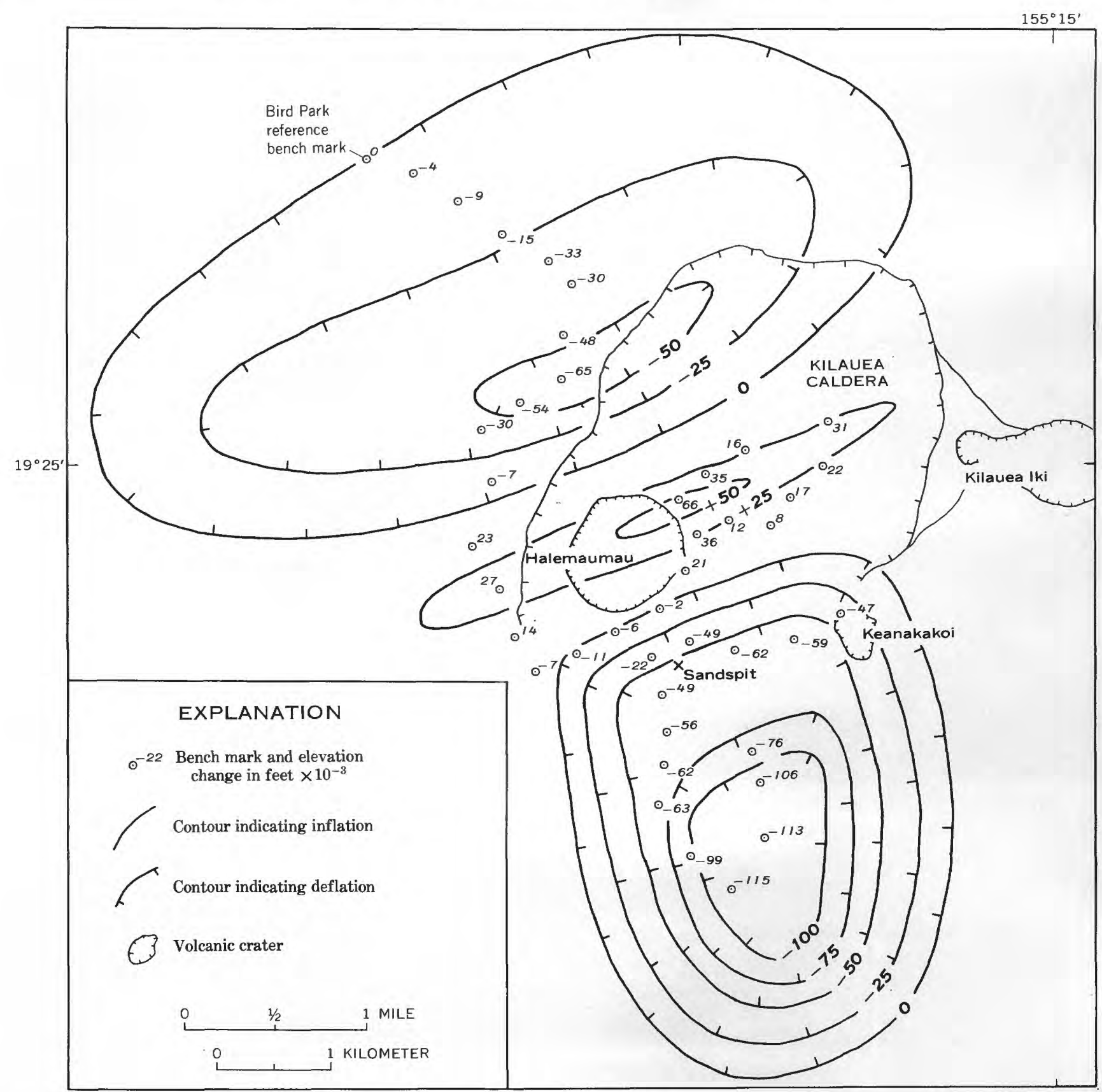

FTaURE 7.-Change in altitude of bench marks in the summit area of Kilauea Volcano for the period June 1965 to January 1966.

tion of December 1965; rather, it merely did not subside to the former level of June 1965. The shape of the subsidence along the northwest margin of the caldera is poorly defined by the few data points available, although its existence seems fairly certain. The overall configuration of the negative area south-southeast of Halemaumau is also poorly known, but, again, it seems to be a genuine feature. The local subsidence in this area probably explains the seemingly anomalous measurement of southeast ground tilt at Sandspit in January 1966 (fig. 3).

Precise leveling of bench marks along the Chain of Craters Road and the Hilina Pali Road in January 1966 revealed major changes of altitude in the area south and southeast of the summit. The bench marks along the Chain of Craters Road were last leveled just after the eruption of March 1965, and thus their change in altitude can be attributed to the deformation 
that took place before and during the activity of December 1965. The bench marks along the Hilina Pali Road were last leveled in July 1963, shortly after two episodes of summit collapse and ground cracking along the Koae fault system. Since July 1963 and before December 1965, there have been three eruptions on the upper east rift zone and one small episode of summit collapse not accompanied by an eruption, but no ground cracking was noted along the Hilina Pali Road following any of these periods of activity. It is probable, therefore, that most of the changes in altitude recorded in January 1966 can be attributed to the activity of December 1965.

The apparent change in altitude at each of the bench marks is shown in figure 8. The scarcity of data permits the contour lines of equal altitude change to be drawn with considerable freedom, and probably with a corresponding lack of accuracy. The "zero change," contour has been drawn to enclose most of the areas broken by ground cracking in December 1965, including the westernmost line of eruptive fissures where cracking was intense. All the bench marks within this contour subsided, locally more than 5 feet. The area of subsidence clearly extends from the Koae fault system eastward into the east rift zone.

Most of the bench marks shown on figure 8, however, had higher altitudes after the activity of December 1965. The five bench marks along the Chain of Craters Road north of the area of subsidence had net increases in altitude ranging from about 0.13 to more than 0.35 foot. The six bench marks east and southeast of the subsided area had even greater uplifts. The reason for this uplift is not fully understood. The measurements either record net inflation of the rift zone that took place before the December 1965 activity, or during the activity itself; in the absence of leveling data for the period just before the eruption of December 1965, it is not known which is more plausible.

Perhaps the most interesting area of uplift lies just south of Kalanaokuaiki Pali along the Hilina Pali Road. Just south of the pali, more than 2.4 feet of uplift was recorded, and lesser amounts of uplift were recorded at the two bench marks father south along the road. Just north of the pali, nearly 6 feet of subsidence was measured, indicating that a total displacement of more than 8 feet took place along the fault at the pali and on nearby smaller faults. Displacements of the same order of magnitude, as substantiated by fieldwork, were found along the pali eastward for 4 miles, to a point just south of Aloi Crater. For this reason, the +1 -foot contour on figure 8 has been extended eastward, just south of Kalanaokuaiki Pali, to the vicinity of the east rift zone. There, the contour has been arbitrarily joined with the one enclosing the uplifted bench marks along the Chain of Craters Road east of Aloi Crater.

The surface of the lava lake, formed in the west pit of Makaopuhi Crater in March 1965, had been leveled eight times before the eruption of December 1965; the ninth leveling of the lake in March 1966 revealed that the entire lake surface had been tilted, presumably during the activity of December 1965 . The strike and dip of the tilted lake surface is shown in figure 8 ; the strike cuts directly across what might have been considered the regional trend of deformation. The data are insufficient to indicate whether the crosscutting contour at Makaopuhi Crater marks the eastern boundary of an area of rather simple uplift or whether it forms part of a more complicated pattern of deformation, the configuration of which could not be outlined by the meager data at hand.

\section{DEPOSITION OF SULFUR}

The choking fumes that billowed from the cracked zone just west of Aloi Crater on the night of the eruption gave the first indication that great quantities of sulfurbearing gases were being liberated. Reconnaissance during the first week after the eruption showed that large amounts of sulfur were being deposited along the sides of many steaming cracks and source fissures between Aloi Crater and Kane Nui o Hamo (fig. 5). Moreover, newly deposited sulfur was noted along some cracks in the steep north wall of Makaopuhi Crater, and scattered occurrences of active sulfur deposition were reported as far away as Napau Crater, 4 miles east of Aloi Crater. Within 3 months, the rate of sulfur deposition slackened considerably, and active deposition continued only near Aloi Crater and at a few places to the east, within about 1 mile. Twenty-five months after the eruption, in January 1968, sulfur deposition had virtually ceased near Aloi Crater, and it persisted only at one locality about half a mile to the east.

\section{DISTRIBUTION AND CHARACTER OF LAVA IAAVA ERUPTED IN ALOI CRATER}

The lava erupted into Aloi Crater poured from two right-offset en echelon fissures that cut northeastward across the floor and walls of the crater (fig. 9). The new lava spread over the December 1962 lava that formed the flat floor of the crater, and, as the eruption continued, it began to fill the crater. When the lava pool reached a depth of about 36 feet, it covered the top of the 1962 drainback, and continued infilling brought the maximum depth of the lava lake to about 47 feet. At this point the lava abruptly began to drain back, either into the 


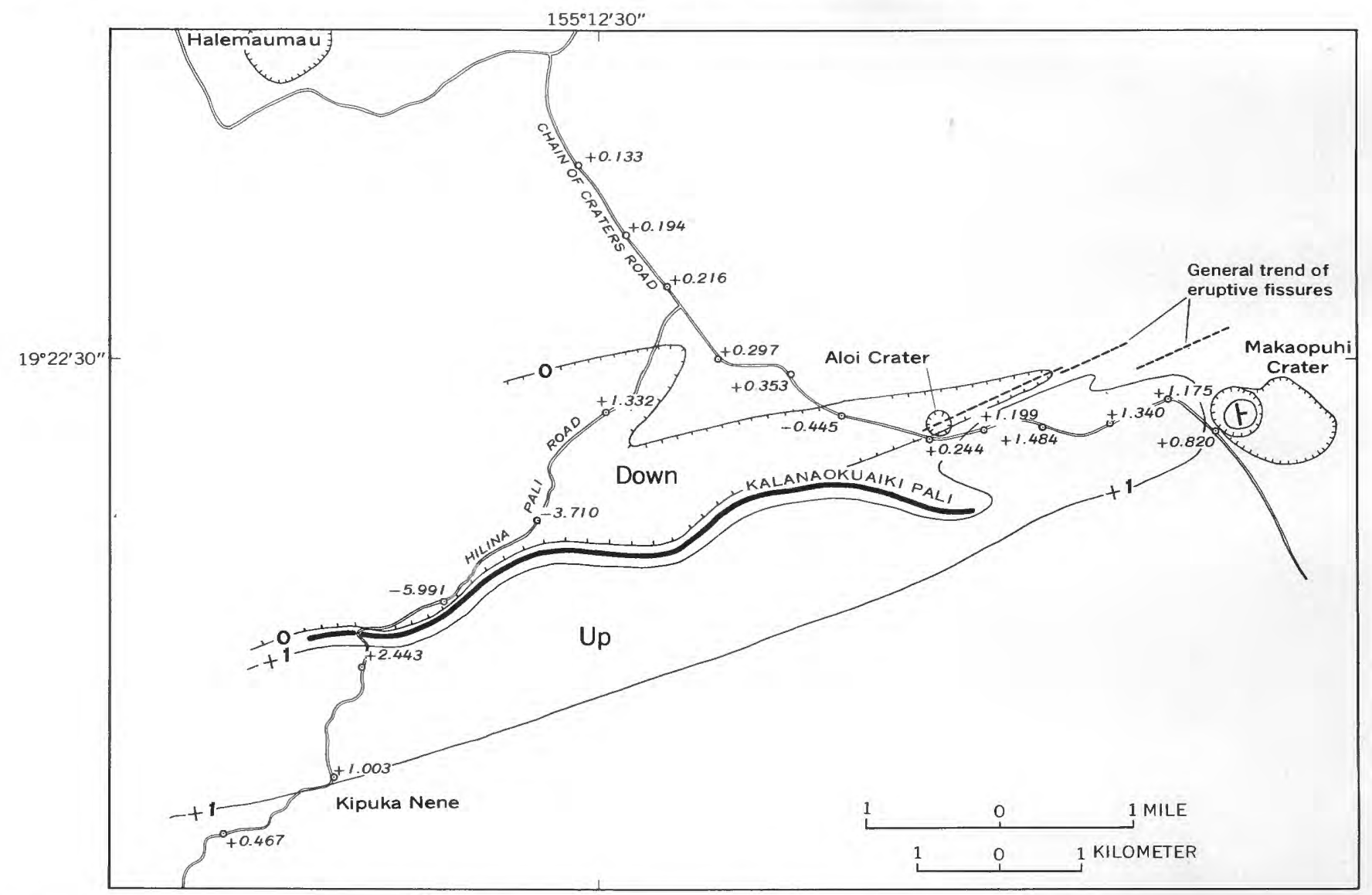

FIGURE 8.- Changes in altitude (in feet) of bench marks along the Chain of Craters Road (for the period March 1965 to January 1966) and along the Hilina Pali Road (for the period July 1963 to January 1966). Only the 0- and +1-foot contours are shown; these are highly schematic. The strike and dip symbol plotted in the west pit of Makaopuhi Crater shows the direction of tilt of the surface of the lava lake after the activity of December 1965.

source fissures or into newly opened cracks that are no longer visible. The lake level quickly lowered about 11 feet, leaving a thin smooth skin of glassy lava encrusting the talus blocks that rim the crater. The drainback continued, but in smaller increments of 1 or 2 feet, and parts of the thin crust that formed during each successive stand of the lava lake are still rooted in the sloping walls of the crater (fig. 9). When the lava lake was about 8 feet deep, the drainback ceased for a short period, and a crust about 5 inches thick developed. Then, at 0140 on December 25, this crust in the southern part of the crater was overturned in a 15-minute episode of crustal foundering that spiraled counterclockwise halfway around the floor of the crater. Renewed drainback then lowered the lake surface a final 3 feet to its present altitude of about 2,942 feet.

In March 1966, a $1_{16}^{3}$-inch hole was drilled 26 feet into the floor of Aloi Crater in an effort to determine the thickness of the lavas of 1965 and 1962 and the nature of the material that floored the crater before the eruption of December 1962. This hole was drilled just over the point where the crustal foundering began in the southern part of the crater (fig. 9); more than 11 feet of core was recovered.

A major flow contact was encountered at 11-12 feet, and the hole was bottomed at 26 feet in soft, oxidized material that presumably lies at or near the bottom of another lava flow. Moore and Krivoy (1964) estimated that the 1962 lava was less than 10 feet thick. The flow contact encountered at a depth of 11-12 feet therefore probably represents the base of the 1962 lava. The contact between the 1962 and 1965 lavas apparently lies at a depth of about 6 or 7 feet, in which interval the drill penetrated 0.5 foot of soft material. Moreover, the abrupt drop in olivine content, from about 1.7 percent in rocks above this interval to about 0.5 percent in rocks below it, also suggests that the base of the 1965 lava lies within the interval, perhaps at a depth of about 6.5 feet.

The rubbly material encountered at 26 feet must therefore mark the approximate base of a prehistoric 
or three served exclusively as source vents for the lava. The remaining fissures served both as source vents and as drainback cracks, and the available evidence suggests that, as the activity progressed, the total rate of drainback gradually exceeded the rate of eruption.

The source fissures are shown on figure 5 ; in the field they are recognized chiefly by the abundance of spatter along their margins and by spatter encrustations on nearby trees. In some places this spatter built low ramparts less than a foot high along the margins of the source fissures. Elsewhere, the ramparts, if ever present, were swept away by the flowing lava, and only the spatter from the very latest stages of the eruption is sprinkled thinly over the lava crust.

Lava drained back into many of the source fissures, many of which are now partly filled by lava, chilled in the process of pouring underground. Moreover, in some places evidence shows that the rate of drainback increased as the activity progressed. In figure 10, for example, thick encrustations of new spatter cover the top of the prehistoric spatter rampart that rises just south (to the right) of the fissure. These encrustations indicate that appreciable amounts of lava fountained from this particular fissure during the early stages of the eruption. The fissure itself, however, is bordered by striking drainback features; their occurrence proves that drainback was dominant during a later period.

The few fissures that apparently served only as drainback cracks are of special interest. The interpretation that these fissures never erupted lava is based only on negative evidence, such as the conspicuous lack of spatter deposits along their margins and the lack of spatter encrustations on nearby trees. Two conspicuous drainback cracks of this type are located about three-quarters of a mile S. $70^{\circ}$ W. from the summit of Kane Nui o Hamo. These cracks deserve particular attention because evidence suggests that they might not have opened intil the eruption was well underway.

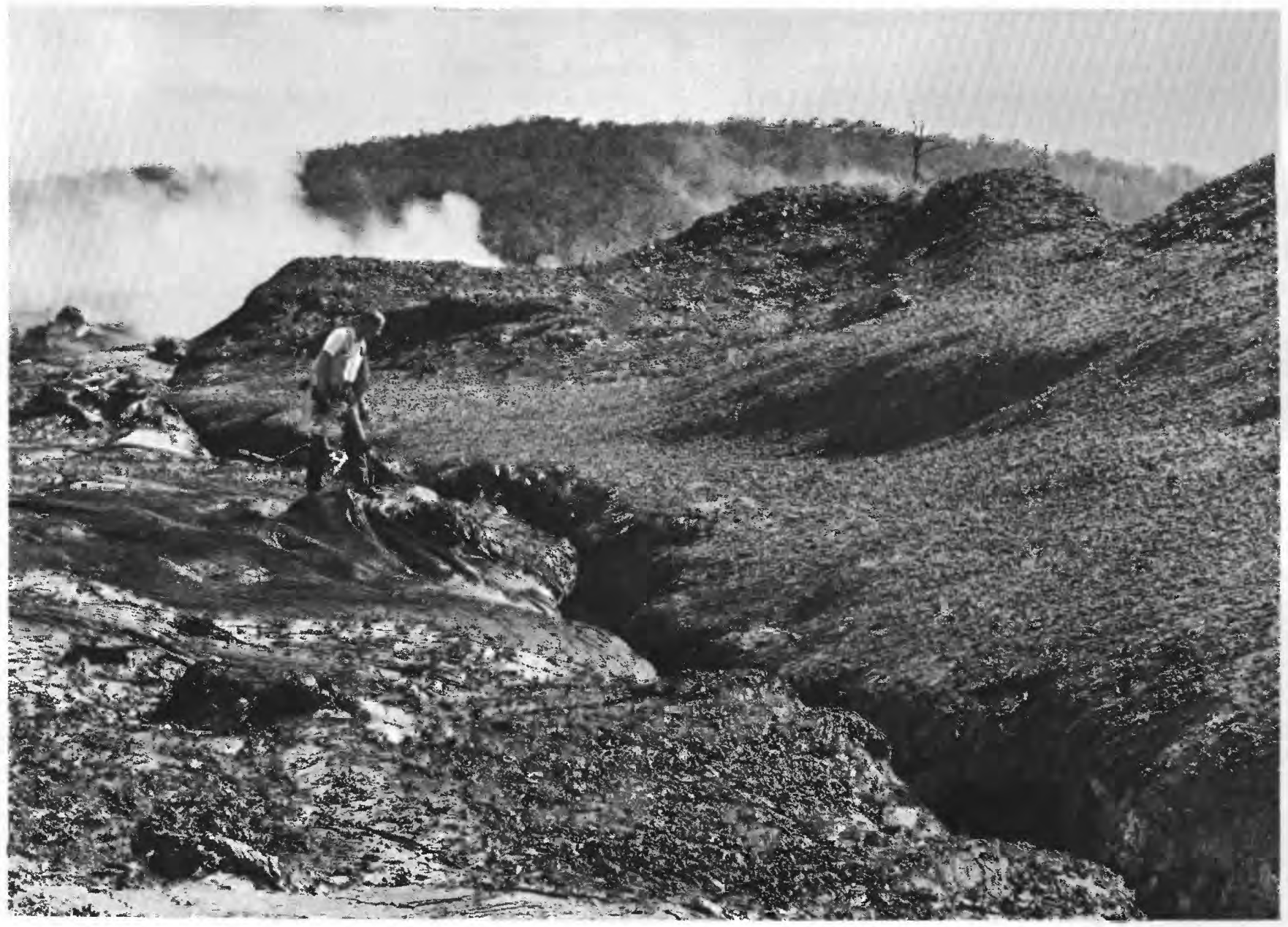

Figure 10.-Source fissure and drainback crack, about 0.5 mile west of the summit of Kane Nui o Hamo. During the early stages of the eruption, large amounts of lava fountained from this fissure and showered a thick layer of new spatter on the prehistoric spatter rampart lying just to the south (right). Later, lava drained into this crack, and conspicuous drainback features occur along its entire length. 
These two cracks are about 260 and 130 feet long, and in places they are as much as 3 feet wide. They happened to open in a fairly dense forest of small ohia trees (Metnosideros sp.), and dozens of tree molds of the type described by Moore and Richter (1962) were formed by the lava that temporarily pooled in the immediate area. As noted by Moore and Richter, the tapered lee side of some tree molds points in the direction that the lava was flowing. The tops of 30 of the 50 tree molds in this small area are strongly tapered and indicate that when the lava was about 5 feet deep it was flowing in a generally northeast direction (fig. 11).

The same general direction of flowage is indicated by the tapered edges about halfway down most of these tree molds, formed when the depth of the lava had lowered to about 2 or 3 feet; this flow direction has also

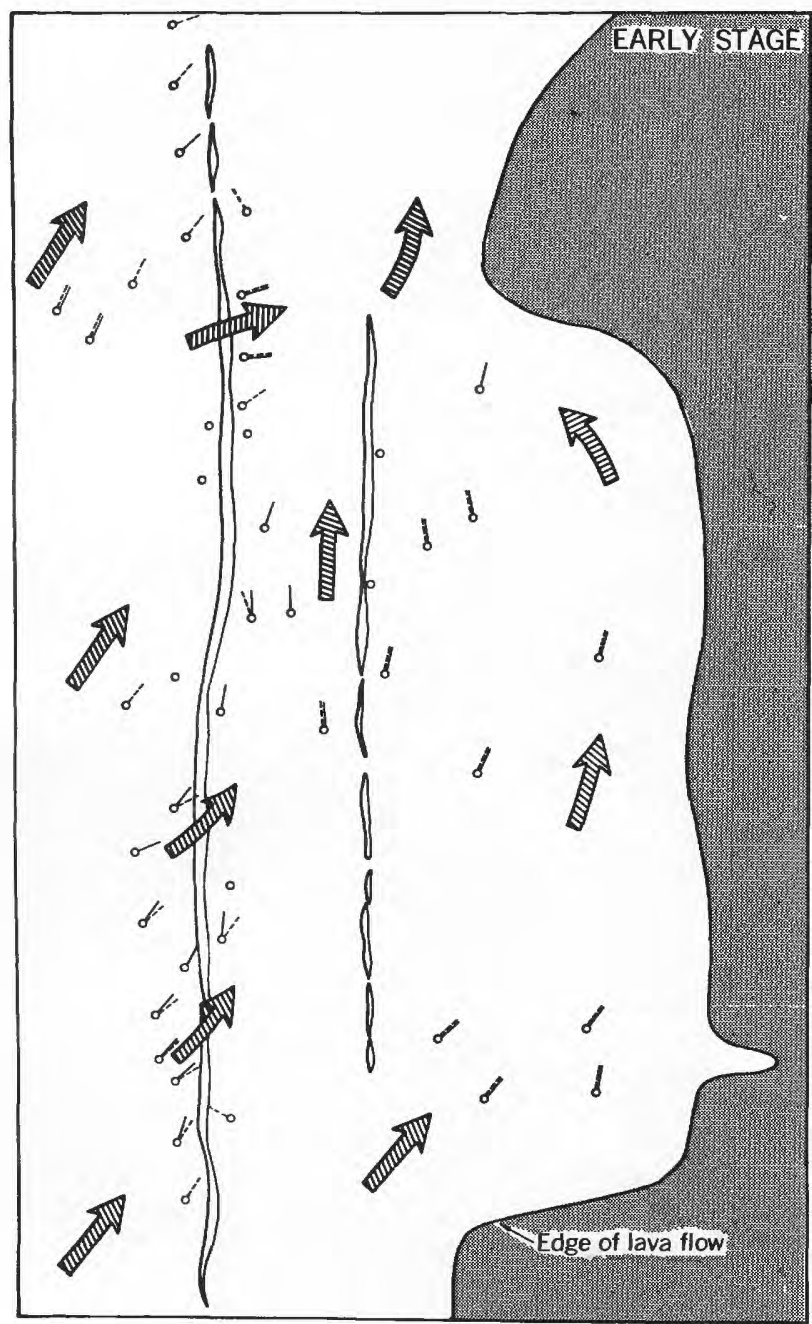

been plotted on figure 11. Below this level, however, the orientation of the tapered edges changes markedly, much as it does on the individual tree mold in figure 12, and the indicated flow directions point strongly toward the two drainback cracks (fig. 11).

Apparently, the lava flowed uniformly eastward during the early part of the eruption when this area was flooded to a depth of about 6 feet. The cracks may have been draining some lava at this time, but the uniform direction of flowage and the nearly planar surface defined by the tops of all the tree molds in this small area suggest that local drainback was slight, if it was taking place at all. As the lava continued to drain eastward the flow level gradually lowered, but after it reached a depth of 2 or 3 feet the flow direction was dominated by drainback into the cracks. Thus, it seems likely that

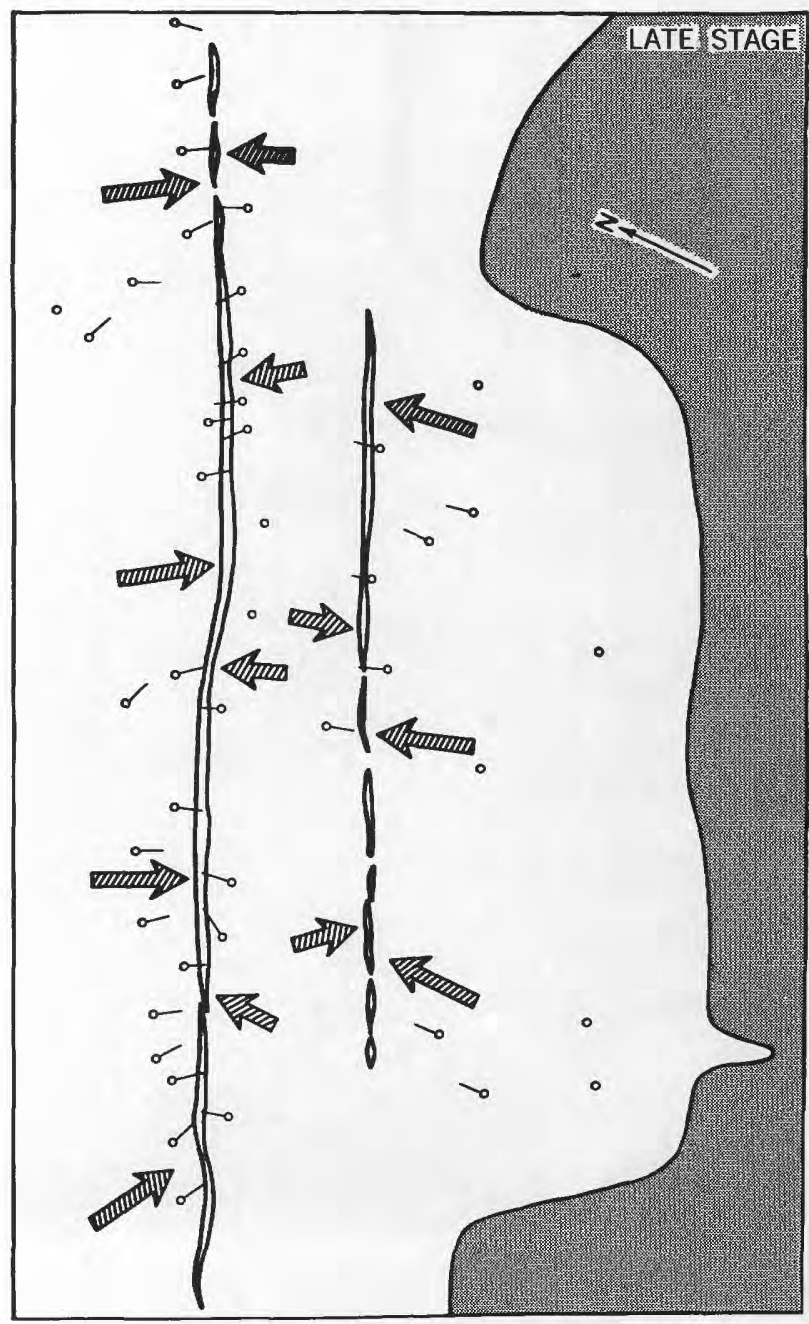

60 FEET

FIGURE 11. Flow directions of lava in a small area 0.75 mile west of Kane Nui o Hamo as indicated by the tapered edges of tree molds. At an early stage (left) the lava flowed in a generally northeast direction, as shown by measurements at the tops of the tree molds (solid lines) and at the middle of the molds (dashed lines). At a later stage (right) local drainback into the cracks caused the flow pattern to change markedly. 
these cracks did not even open, or at least that they did not drain to any great extent, until late in the eruption when the depth of lava in this area had lowered to 2 or 3 feet.

The fact that the slender tree trunks inside of the tree molds in this area did not burn (fig. 12) indicates that the whole process of rise and fall of the lava, as described above, probably took place in a very short time, perhaps in a matter of a few minutes.

\section{CRUSTAL FOUNDERING}

From 0400 to about 0405 on December 25, the thin, solidified crust overlying the shallow, stagnant lava pool just west of Kane Nui o Hamo apparently was overturned during a brief period of crustal foundering.

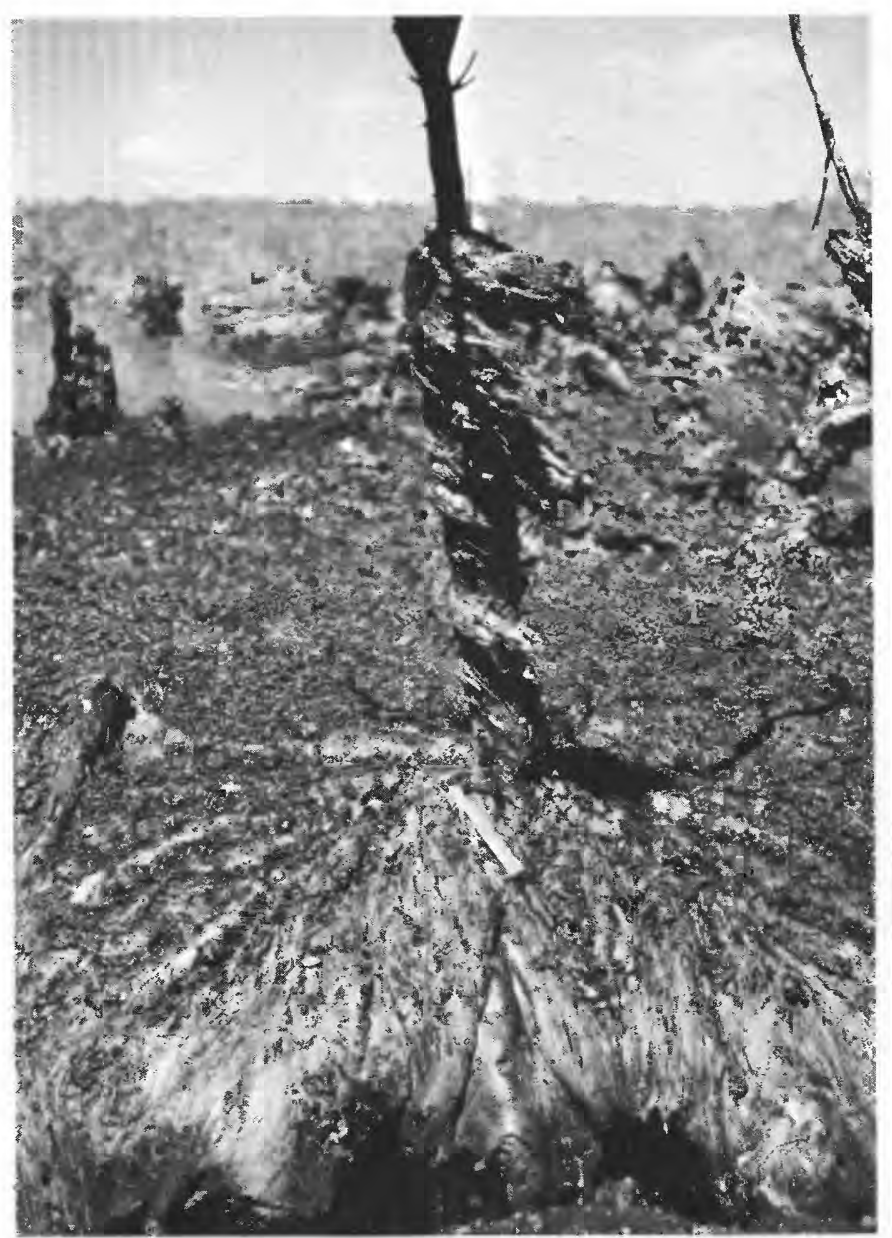

Figure 12.-Spiral tree mold 0.75 mile west of Kane Nui o Hamo. The jagged, tapered edge near the top of this 5 -foot tree mold points to the right (east). Lower down on the mold, this edge spirals through an angle of nearly $90^{\circ}$ and points directly toward the open drainback crack in the foreground. When the depth of lava first began to decrease in this area, the direction of fiow is interpreted to have been from left to right. Late-stage drainback caused the flow to change direction and pour directly into the open crack.
Although this foundering was not actually observed, the brilliant glow that resulted from it was seen (p. 3), and the structures and textures it formed are identical with those produced by the observed crustal foundering in Aloi Crater during the early hours of December 25.

The total area affected by this overturning is about 10 acres and is shown by the crosshatching in figure 5 . All along the edge of this area a second crust, formed by the overturning, overrides the older crust, and in places, tilted slabs of older crust have been frozen in the position of foundering (fig. 13). In addition, the ropy surfaces and flow channels, so typical of the older crust (right foreground, fig. 13), are virtually absent in the lava that welled to the surface during the overturn.

\section{VOLUME OF IAAVA}

About 400,000 cubic yards of lava initially poured into Aloi Crater; however, all but 40,000 cubic yards drained away shortly after it was erupted.

East of Aloi Crater, about 150 acres of forest was flooded by lava, and measurements of the depths of hollow tree molds gave an average flow thickness of 3 feet. Thus, about 730,000 cubic yards of lava remains on the surface east of the crater, but this figure does not include the unknown volume of lava that drained into the source fissures and drainback cracks.

Therefore, a total of at least 1,130,000 cubic yards of basalt lava was erupted during the brief activity of December 1965; of this total, about 360,000 cubic yards drained back, leaving something on the order of 770,000 cubic yards of lava remaining on the surface.

\section{PETROLOGY AND CHEMISTRY}

The lava of December 1965 is an olivine-poor tholeiitic basalt, and the 15 specimens examined in thin section contain from 3.1 to 0.7 percent olivine. The olivine occurs chiefly as microphenocrysts, rarely exceeding 0.5 $\mathrm{mm}$ in diameter; microphenocrysts of plagioclase and pyroxene are very sparse. Modes of 10 specimens are given in table 1.

The most glassy specimen of pumice (Aloi 65-1) contains 0.7 percent olivine in well-formed microphenocrysts, only 0.2 percent pyroxene in ragged aggregates scattered sparsely through the rock, and no trace of plagioclase. Plagioclase was observed only in rocks containing less than 91 percent glass, and opaques (ilmenite $>$ magnetite) are present only in the much more crystalline specimens. These relations suggest that the paragenesis of the main phases was olivine-pyroxene-plagioclase-opaques, the same order observed in the 1959 lava erupted in Kilauea Ski (Richter and Murata, 1966), and in the 1965 lava erupted in Makaopuhi Crater (Sato and Wright, 1966). 


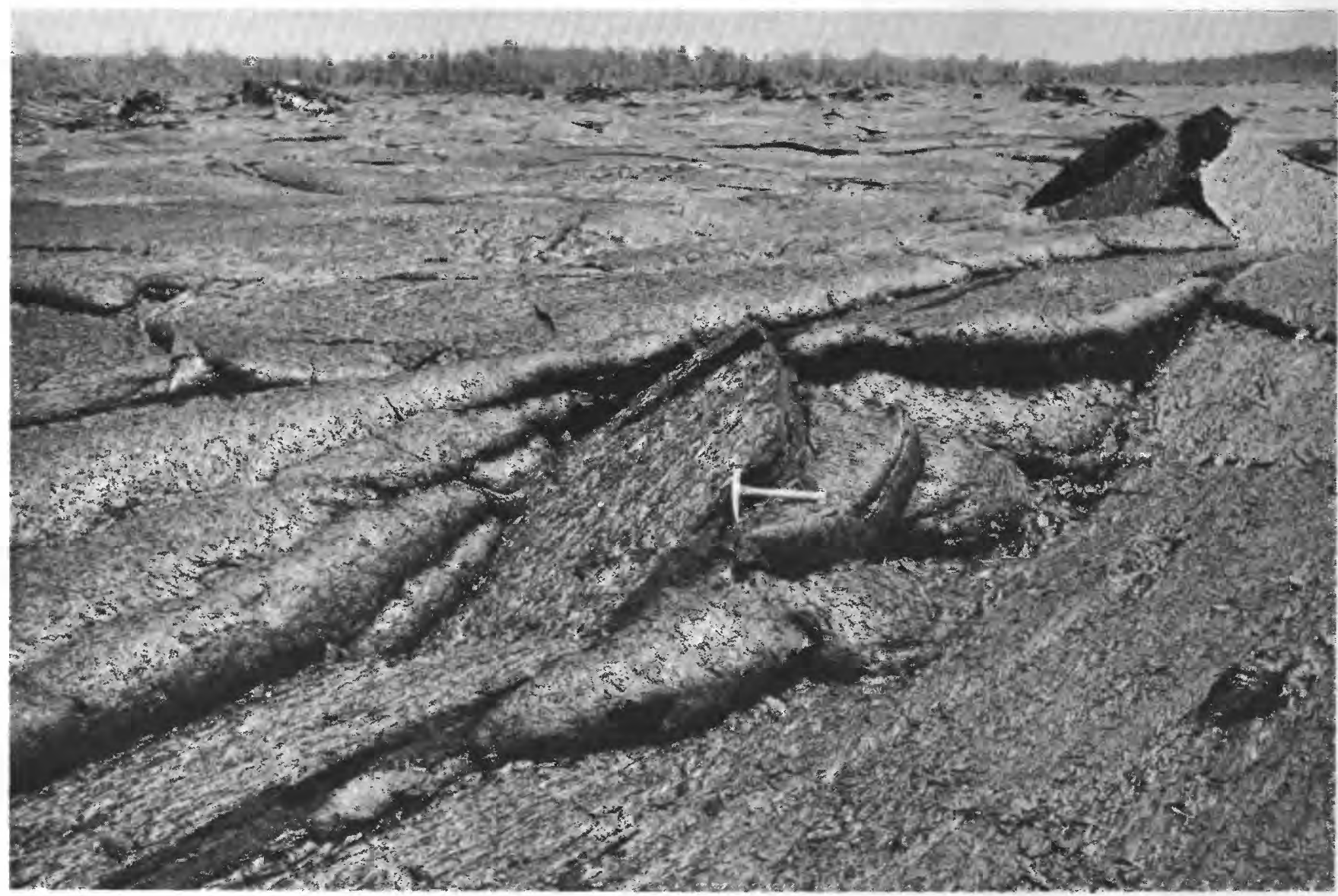

Frgure 13.-Edge of area affected by crustal foundering, 0.5 mile west of Kane Nui o Hamo. Tilted slab of older crust is partly enveloped by frothy lava that welled to the surface during the period of crustal foundering. Note that the surface of the slab and the lava in the foreground contain a pronounced flow lineation, whereas the surface of the younger crust is nearly structureless.

Chemical analyses of three specimens of December 1965 lava are given in table 2. Sample 1 consists of pumice erupted from Aloi Crater at about 2200 on December 24. Sample 2 is spatter collected from the surface of the lava remaining in Aloi Crater; this material was observed erupting shortly after midnight on the 24 th. The precise time that sample 3 was erupted is not known, but because the fountaining east of Aloi Crater continued for several hours after the eruption in the crater had ended, it is possible that it was not emplaced until 0200 or 0400 on December 25. Therefore, in the brief span of 4 or 6 hours represented by the specimens analyzed, little change took place in the chemistry of the lava erupted to the surface.

\section{DISCUSSION}

The summit area of Kilauea Volcano inflated and collapsed before and after the eruption of December 1965 in much the same way that it has before and after each of the recent eruptions from the east rift zone

TABLE 1.-Modal composition of lava from the December 1965 eruption of Kilauea Volcano, in volume percent

\begin{tabular}{|c|c|c|c|c|c|c|c|}
\hline Field No. & Description & Olivine & Pyroxene & Plagioclase & Opaques 1 & Glass & $\begin{array}{l}\text { Number } \\
\text { of points }\end{array}$ \\
\hline Aloi 65-1 & Pumice erupted from Aloi Crater. & 0.7 & 0.2 & & & 99.1 & 1,000 \\
\hline & do do & 1.8 & -4 & & $\ldots . . .$. & 97.8 & 1,000 \\
\hline$\frac{9}{7}$ & $\begin{array}{l}\text { Glassy spatter erupted } 0.5 \text { mile west of Kane Nui o Hamo } \\
\text { Glassy spatter erupted } 0.75 \text { mile west of Kane Nui o Hamo }\end{array}$ & 2.7 & $\begin{array}{r}8.3 \\
14.2\end{array}$ & Trace $^{0.3}$ & (n) & $\begin{array}{l}90.7 \\
83.5\end{array}$ & 1,000 \\
\hline 5 & $\begin{array}{l}\text { Glassy spatter from surface of lava in Aloi Crater } \\
\text { Drill core, Aloi Crater, depth: }\end{array}$ & 3.1 & 14.9 & 1.2 & - & 80.9 & 1,000 \\
\hline 14 & $4 \mathrm{ft}$ & 1.6 & 39.2 & 17.3 & 8.8 & 33.1 & 1,000 \\
\hline 11 & $0.75 \mathrm{ft}$ & 1.5 & 45.9 & 23.0 & 7.1 & 22.5 & 1,000 \\
\hline 15 & $5 \mathrm{ft}$ & 1.5 & 45.4 & 23.4 & 7.9 & 21.8 & 1,000 \\
\hline $\begin{array}{l}13 \\
12\end{array}$ & $2.5 \mathrm{ft}$ & $\begin{array}{l}1.9 \\
1.8\end{array}$ & $\begin{array}{l}49.0 \\
52.9\end{array}$ & $\begin{array}{l}24.7 \\
23.8\end{array}$ & $\begin{array}{l}7.0 \\
7.8\end{array}$ & $\begin{array}{l}17.4 \\
13.7\end{array}$ & 1,000 \\
\hline
\end{tabular}

1 Many of the opaques are diffcult to distinguish from oxidized glass; the volume percentages for opaques and for glass may therefore be somewhat in error. 
TABLE 2.-Chemical analyses and norms of lava from the December 1965 and December 1962 eruptions of Kilauea Volcano

[Results in weight percent. Samples 1-3, December 1965, G. O. Riddle, analyst; samples 4 and 5, December 1962, E. L. Munson, analyst]

\begin{tabular}{|c|c|c|c|c|c|}
\hline & (1) & (2) & (3) & (4) & (5) \\
\hline $\begin{array}{l}\text { Laborator } \\
\text { Fileld No. }\end{array}$ & $\begin{array}{r}\text { D101417 } \\
\text { Aloi 65-1 }\end{array}$ & $\begin{array}{l}\text { D101418 } \\
\text { Alo1 } 65-5\end{array}$ & $\begin{array}{c}\text { D101419 } \\
\text { Aloi } 65-7\end{array}$ & $\underset{\text { H-301 }}{\text { W162184 }}{ }^{1}$ & $\underset{H-304}{W 1621851}$ \\
\hline \multicolumn{6}{|c|}{ Chemical analysea } \\
\hline $\begin{array}{l}\mathrm{SiO}_{2} \\
\mathrm{Al}_{2} \mathrm{O}_{3} \\
\mathrm{Fe}_{2} \mathrm{O}_{3} \\
\mathrm{FeO} \\
\mathrm{MgO} \mathrm{O}_{-} \\
\mathrm{CaO} \\
\mathrm{Na}_{2} \mathrm{O} \\
\mathrm{K}_{2} \mathrm{O} \\
\mathrm{H}_{2} \mathrm{O} \\
\mathrm{H}_{2} \mathrm{O}- \\
\mathrm{TiO}_{2} \\
\mathrm{P}_{2} \mathrm{O}_{5} \\
\mathrm{MnO} \mathrm{CO}_{2} \\
\mathrm{Cl}_{2}\end{array}$ & $\begin{array}{r}50.29 \\
13.77 \\
1.33 \\
9.87 \\
7.74 \\
11.08 \\
2.36 \\
.55 \\
.12 \\
.01 \\
2.56 \\
.27 \\
.17 \\
.00 \\
.02 \\
.05\end{array}$ & $\begin{array}{r}50.35 \\
13.64 \\
1.19 \\
10.05 \\
7.72 \\
11.06 \\
2.31 \\
.55 \\
.07 \\
.00 \\
2.63 \\
.27 \\
.17 \\
.01 \\
.02 \\
.04\end{array}$ & $\begin{array}{r}50.34 \\
13.58 \\
1.23 \\
9.97 \\
7.85 \\
11.05 \\
2.33 \\
.55 \\
.02 \\
.02 \\
2.70 \\
.28 \\
.17 \\
.01 \\
.01 \\
.04\end{array}$ & $\begin{array}{r}51.13 \\
13.81 \\
2.20 \\
9.99 \\
5.67 \\
9.63 \\
2.76 \\
.74 \\
.05 \\
.02 \\
3.56 \\
.38 \\
.18 \\
.02 \\
.02 \\
.05\end{array}$ & $\begin{array}{r}50.45 \\
13.43 \\
3.16 \\
8.41 \\
7.49 \\
10.74 \\
2.42 \\
.59 \\
.01 \\
.00 \\
2.88 \\
.30 \\
.18 \\
.01 \\
.02 \\
.04\end{array}$ \\
\hline $\begin{array}{l}\text { Subtotal } \\
\text { Less 0 }\end{array}$ & $\begin{array}{r}100.19 \\
.02\end{array}$ & $\begin{array}{r}100.08 \\
.02\end{array}$ & $\begin{array}{r}100.15 \\
.02\end{array}$ & $\begin{array}{r}100.22 \\
.02\end{array}$ & $\begin{array}{r}100.13 \\
.02\end{array}$ \\
\hline Total. & 100. 17 & 100.06 & 100. 13 & 100.20 & 100. 11 \\
\hline \multicolumn{6}{|c|}{ Norms } \\
\hline $\begin{array}{l}\text { Q } \\
\text { Or } \\
\text { Ab } \\
\text { An } \\
\text { Di: }\end{array}$ & $\begin{array}{r}3.34 \\
19.91 \\
25.30\end{array}$ & $\begin{array}{r}.42 \\
3.34 \\
19.39 \\
25.02\end{array}$ & $\begin{array}{r}.06 \\
3.34 \\
19.91 \\
24.74\end{array}$ & $\begin{array}{r}3.90 \\
4.45 \\
23.58 \\
22.80\end{array}$ & $\begin{array}{r}\text { 3. } 06 \\
\text { 3. } 34 \\
20.44 \\
23.91\end{array}$ \\
\hline $\begin{array}{l}\text { Wo } \\
\text { En } \\
\text { Fs }\end{array}$ & $\begin{array}{r}11.60 \\
6.60 \\
4.49\end{array}$ & $\begin{array}{r}\text { 11. } 60 \\
6.60 \\
4.49\end{array}$ & $\begin{array}{r}\text { 11. } 72 \\
6.70 \\
4.49\end{array}$ & $\begin{array}{l}\text { 9. } 28 \\
\text { 5. } 00 \\
\text { 3. } 96\end{array}$ & $\begin{array}{r}\text { 11. } 25 \\
7.20 \\
3.30\end{array}$ \\
\hline $\begin{array}{l}\text { En } \\
\text { Fs. }\end{array}$ & $\begin{array}{r}12.70 \\
8.45\end{array}$ & $\begin{array}{r}12.70 \\
8.84\end{array}$ & $\begin{array}{r}12.70 \\
8.58\end{array}$ & $\begin{array}{l}9.20 \\
7.00\end{array}$ & $\begin{array}{r}11.50 \\
5.15\end{array}$ \\
\hline $\begin{array}{l}\text { Fo } \\
\text { Fa_. } \\
\text { Il } \\
\text { Ap }\end{array}$ & $\begin{array}{r}.09 \\
.07 \\
1.86 \\
4.86 \\
.67\end{array}$ & $\begin{array}{r}1.86 \\
5.02 \\
.67\end{array}$ & $\begin{array}{r}1.86 \\
5.17 \\
.67\end{array}$ & $\begin{array}{l}\text { 3. } 25 \\
6.84 \\
1.01\end{array}$ & $\begin{array}{r}4.64 \\
\text { 5. } 47 \\
.67\end{array}$ \\
\hline Total_... & 99.94 & 99.95 & 100.14 & 100.27 & 99. 93 \\
\hline
\end{tabular}

1 Tholeiitic basalts erupted in and near Aloi Crater, December 1062. Analyses of these specimens, previously reported by Moore and Krivoy (1964, table 2), were later found to be in error. For the record, new analyses of the same specimens are given here.

1. Pumice erupted from Alol Crater, Dec. 24, 1965.

2. Glassy spatter erupted onto surface of lava in Aloi Crater, Dec. 24, 1965.

3. Glassy spatter erupted 0.75 mile west of Kane Nui o Hamo, Dec. 24 or 25,1965

.

5. Lava from floor of Aloi Crater, erupted Dec. 7,1962 .

(Eaton and Murata, 1960; Richter and others, 1964; Moore and Krivoy, 1964). As outlined by these authors, and demonstrated in figure 2 of this report, the summit of the volcano gradually swells as magma accumulates within the central reservoir area. This accumulation continues until a point of failure is reached, and magma then travels laterally into the east rift zone where it is either erupted to the surface or remains underground in the form of dikes or other intrusive bodies. The with- drawal of magma from the summit reservoir causes an abrupt collapse of the summit area, and the cycle of reservoir filling then begins again.

In contrast, the eruption of December 1965 was the briefest $(6 \mathrm{hr}$ ) of any of the recent flank eruptions, but the seismic crisis that accompanied and followed the eruption was great, in both number of earthquakes and duration. The brevity of the eruption and the intensity of the seismic crisis are quite possibly related, especially when consideration is given to the overall chronology of the rate of eruption, tremor amplitude, earthquakes. ground cracking, and summit tilt.

The net rate of eruption, as shown diagramatically in figure 4, clearly was not a function only of the rate at which lava was erupted from the source fissures, for lava was draining back throughout much of the time that it was being erupted, so that the net rate of lava. added to the surface was actually the resultant of both eruption and drainback.

Because so little of the eruption was actually observed, the exact time relations between eruption and drainback are unknown, but field evidence suggests that drainback began abruptly and was the dominant process during the later part of the activity. The thin, glassy skin forming the upper part of the drainback on the walls of Aloi Crater indicates a very rapid withdrawal of lava. Observations made at midnight of December 24 showed that the lava lake in Aloi Crater had completely drained only $31 / 2$ hours after the eruption began, and the period of most rapid drainback possibly took place less than 2 hours after the eruption began.

Even less is known about the timing of drainback of the flows in the east, but the slender unburned tree trunks at the center of many tree molds (fig. 12) clearly indicate rapid rise and equally rapid fall of the lava level, at least locally. By far, the best preservation of woody material at the core of tree molds is in the area adjacent to the cracks shown in figure 11 . These cracks are believed to have drained large volumes of lava in the later stages of the eruption.

Drainback into source fissures and other cracks is a common feature of Kilauean eruptions, and it generally has been ascribed to the loss of volatiles and resulting decrease in the volume of magma within the near-surface system of source fissures (Moore and Krivoy, 1964, p. 2044). Such an argument implies that the volume and overall configuration of the underground system of feeding channels remains about the same; but remembering the extensive ground movements that were taking place as the eruption was waning, it seems pertinent in this instance to consider the opposite case-one in 
which drainback is caused chiefly by changes in the volume of underground feeding channels.

Hundreds of old and new cracks opened at the surface in the upper east rift zone and along the Koae fault system during the activity of December 1965, and the clustering of earthquake epicenters in the same area suggests that similar disruptions were also taking place at depth. According to the model suggested here, magma was able to erupt to the surface only during the early stages of the activity when the system of underground feeding channels was newly formed and still remained relatively intact. Later, as the area was progressively cracked and broken, the feeding channels were disrupted, and new zones of weakness were formed at depth. The magma, which formerly streamed upward to the surface, now had other avenues of escape within the newly fracture rift zone and surface eruption soon ceased. As the volume of underground space became greater, lava began to drain back into the source fissures. Thus, the few cracks that first opened at this late stage, such as those in figure 11, could only serve as drainbacks.

Significantly when the eruption ended at 0400 on December 25, the seismic crisis, as measured by the number of earthquakes per hour, was just reaching its maximum, and it continued at a very high level for the next 10 hours. Ground cracking, tremor amplitude, and collapse of the summit also continued vigorously for the same period, strongly suggesting that a major instrusive event within the upper east rift zone was well underway.

In conclusion, it is interesting to speculate as to the direction of the net displacement that resulted from the considerable ground movements south and southeast of the summit area. Figure 14 shows a very generalized picture of these displacements as suggested by the limited data available. The tensional opening of many of the cracks in the Koae fault system clearly suggests dilation perpendicular to the trend of the system, and it seems likely that much of this dilation would be accommodated by seaward movement of the area south of the Koae fault system. Numerous tension cracks also opened along the upper east rift zone, but the deformation plan in this area was complicated by the apparent right-lateral displacement along most of the cracks. Nevertheless, a general dilation of the rift zone is definitely indicated and, again, movement of the south flank of the volcano seems likely. Accordingly, arrows showing seaward displacement have been placed on figure 14 in the area just south of the region where dilation and subsidence were the greatest.
The Koae fault system and part of the upper east rift zone could therefore be considered to have acted as a complex keystone graben during the activity of December 1965. As the south flank of the volcano moved saaward, this complex graben adjusted to the lateral extension by subsiding, locally more than 5 feet. Moreover, as documented by the abnormally large tilt at the Kalihipaa station (fig. 3), some blocks in this disturked area rotated as they subsided. In the past, movements similar to those of December 1965 doubtless have occurred repeatedly along the Koae fault system, and they probably explain the highly jumbled and disrupted aspect of much of the region.

It is not clear whether the seaward movement of the area south of Kalanaokuaiki Pali (fig. 14) was of the gravity-slide type, as proposed by Moore and Krivoy (1964), or whether it was the result of lateral wedging due to forceful instrusion of magma in the upper esst rift zone. If the movement had been of the gravity-slide type, it seems reasonable that the area south of the pali should have moved downward, and that the greatsst subsidence would have taken place just south of the pali. Meager tilting and leveling data have suggested, on the other hand, that at least part of the block, bounded by Kalanaokuaiki Pali on the north and the Hilina Pali fault system on the south, actually went up rather than down. The pertinent tilt and leveling data illustrating this relationship have been projected onto line $A-A^{\prime}$ of figure 14. (See profile, fig. 15.) The amount of uplift increases nonlinearly as Kalanaokuaiki Pali is rpproached, indicating that the area was not deformed by simple seaward tilting. J. G. Moore and J. P. Eaton (oral commun., 1967) suggested that this uplift actually represents elastic rebound due to the sudcen release of accumulated stresses along Kalanaokuaiki Pali. According to this scheme, which seems quite plausible, graben collapse in the Koae fault system in recent years $(1938,1950,1960,1963)$ produced stresses tl at were not completely released by movement on Kalanaokuaiki Pali, and the area south of the pali was bent downward. During the activity of December 1965, however, these stresses were released, and the area to the south rebounded upward. Such a mechanism might well explain the general shape of the deformation curve in figure 15.

All these structural interpretations must remsin speculative, however, until more data are available. It is hoped that the deformation associated with future periods of activity can be monitored in even greater detail, and thus aid in obtaining a better understanding of the interesting structural relations in the upper east $\mathrm{r}$ :ft zone and Koae fault system. 


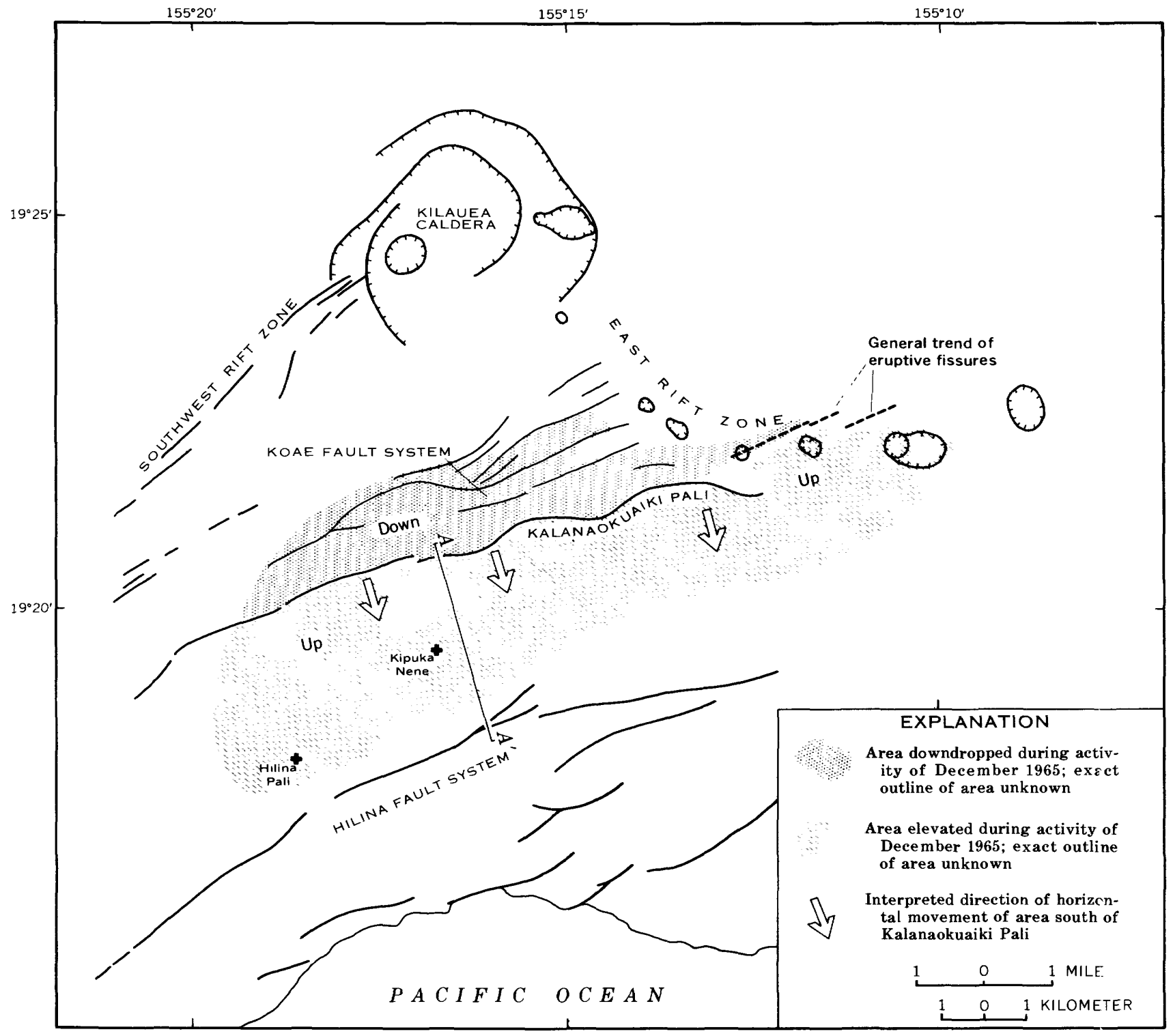

Figure 14.-Possible displacements of the area south and southeast of Kilauea caldera as a result of the activity of December 1965 . 


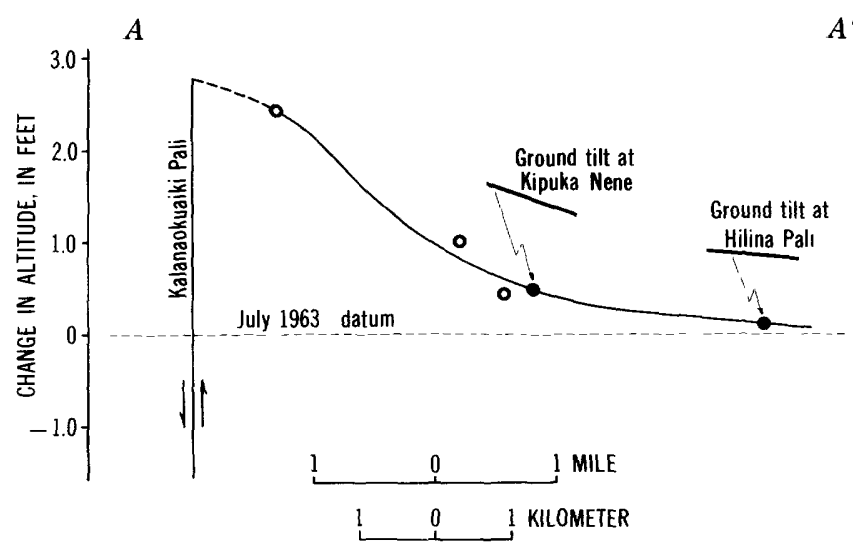

Figure 15.-Profile showing altitude and tilt changes south of Kalanaokuaiki Pali for the period July 1963 to January 1966. The leveling and tilt data have been projected to the section line from nearby stations; the magnitude of ground tilt was obtained by vector summation of the measured tilt at Kipuka Nene and Hilina Pali. Location of section shown in figure 14.

\section{REFERENCES CITED}

Eaton, J. P., and Murata, K. J., 1960, How volcanoes grow: Science, v. 132, no. 3432, p. 925-938.

Finch, R. H., 1950, The December 1950 subsidence at Kilauea [Hawaii] : Volcano Letter, no. 510, p. 1-3.
Jaggar, T. A., 1938, Hawaiian Volcano Observatory report for May 1938: Volcano Letter, no. 459, p. 2-4.

Kinoshita, W. T., 1968, May 1963 earthquakes and deformtion in the Koae fault zone, Kilauea Volcano, Hawaii : U.S. Geol. Survey Prof. Paper 575-C, p. C173-C176.

Moore, J. G., and Krivoy, H. L., 1964, The 1962 flank eruptinn of Kilauea Volcano and structure of the east rift zore: Jour. Geophys. Research, v. 69, no. 10, p. 2033-2045.

Moore, J. G., and Richter, D. H., 1962, Lava tree molds of the September 1961 eruption, Kilauea Volcano, Hawaii: Geol. Soc. America Bull., v. 73, p. 1153-1158.

Richter, D. H., Ault, W. U., Eaton, J. P., and Moore, J. G., 1E64, The 1961 eruption of Kilauea Volcano, Hawaii, in Shorter contributions to general geology: U.S. Geol. Survey Prof. Paper 474-D, 34 p.

Richter, D. H., and Murata, K. J., 1966, Petrography of the lavas of the 1959-60 eruption of Kilauea Volcano, Hawe ii : U.S. Geol. Survey Prof. Paper 537-D, 12 p.

Sato, Motoaki, and Wright, T. L., 1966, Oxygen fugacities directly measured in magmatic gases: Science, $\nabla .153$, no. 3740, p. 1103-1105.

Wright, T. L., Kinoshita, W. T., and Peck, D. L., 1968, mhe March 1965 eruption of Kilauea Volcano, and the formation of Makaopuhi lava lake: Jour. Geophys. Research (in press). 